\title{
Gradients, species richness and communities in eastern Finnish sloping fens
}

\author{
Jarmo Laitinen ${ }^{1, *}$, Jari Oksanen², Eero Kaakinen ${ }^{3}$, Tomáš Peterka ${ }^{4}$, \\ Asbjørn Moen ${ }^{5} \&$ Teemu Tahvanainen ${ }^{6}$
}

1) Department of Ecology and Genetics, P.O. Box 3000, Fl-90014 University of Oulu, Finland ( ${ }^{*}$ corresponding author's e-mail: jarmo.laitinen@oulu.fi)

2) Finnish Museum of Natural History, P.O. Box 7, FI-00014 University of Helsinki, Finland

3) Kurkelantie $1 \mathrm{D}$ 38, Fl-90230 Oulu, Finland

4) Department of Botany and Zoology, Masaryk University, Kotlářská 2, CZ-61137 Brno, Czech Republic

5) Department of Natural History, NTNU University Museum, Norwegian University of Science and Technology, NO-7491 Trondheim, Norway

6) Department of Environmental and Biological Sciences, Faculty of Science and Forestry, University of Eastern Finland, P.O. Box 111, Fl-80101 Joensuu, Finland

Received 17 Apr. 2019, final version received 31 May 2021, accepted 1 June 2021

Laitinen J., Oksanen J., Kaakinen E., Peterka T., Moen A. \& Tahvanainen T. 2021: Gradients, species richness and communities in eastern Finnish sloping fens. - Ann. Bot. Fennici 58: 289-312.

In Scandinavia, three gradients (poor-rich, water table, margin-expanse) are considered in vegetation classification of mires. We re-analysed the data of Paavo Havas from 1961 on sloping fens in eastern Finland using NMDS ordination analysis, which also revealed a three-dimensional structure of the classic gradients, with the poor-rich gradient associated with $\mathrm{pH}$. Water table level, and the unstable-stable water regime gradient were also of importance. Our analysis confirmed the interpretation by Havas but further stressed the role of the poor-rich gradient as the main direction of variation in sloping fens. Species richness increased with $\mathrm{pH}$, and from mire expanse to margin vegetation, but decreased towards too wet or seasonally too dry conditions. Eastern Finnish sloping-fen plant communities resemble those in sloping fens elsewhere in Scandinavia, but also those in montane-subalpine-alpine fens in central and southeastern Europe.

\section{Introduction}

In recent years, studies to quantify both environmental gradients and vegetation types across large areas have been undertaken, as knowledge of the distributions of vegetation types is particularly important for conservation and management (Jiménez-Alfaro et al. 2013, Douda et al. 2015, Peterka et al. 2017 Laitinen et al. 2019).
Results obtained at the regional level often serve as references and are used to validate those from continental-scale studies developing classifications and surveying of larger-scale distribution patterns of vegetation types. To date, however, studies on the links between environmental gradients and mire vegetation types recognized in different parts of Europe are few (see Laitinen et al. 2017). 
Recently, the focus of traditional mire vegetation surveys in Europe has clearly turned from Scandinavia to central Europe (see e.g. Hájek et al. 2006, Pawlikovski et al. 2013). Peterka et al. (2017) made the first attempt to create a classification system for European fen communities (minerotrophic mires of the Scheuchzerio palustris-Caricetea fuscae class) at the alliance level. The system used in their study followed the Braun-Blanquet approach, and was consistent with the synopsis of nomenclaturally valid highrank syntaxa in Europe (Mucina et al. 2016).

In Finland, vegetation surveys (Cajander 1913) begun long before adoption of classification schemes with the three following gradients: poor-rich gradient (Sjörs 1952, Sjörs \& Gunnarsson 2002, Tahvanainen 2004), mire surfacelevel gradient (hummock level-lawn-flark level including carpet and mud-bottom; Sjörs 1948, Laitinen et al. 2008a), and mire margin-expanse complex gradient (Sjörs 1948, Joosten et al. 2017). These gradients served as a basis for vegetation classification (Ruuhijärvi 1960, Persson 1962), and were later analysed with modern methods of data analysis (Pakarinen \& Ruuhijärvi 1978, Moen 1990, Moen et al. 2011).

A physiognomic mire margin-expanse concept (see Økland et al. 2001) discriminates between mire margin and expanse communities based on the occurrence of trees. However, many Finnish studies (Ruuhijärvi 1960, Eurola \& Kaakinen 1978, Eurola et al. 1984, 1995, 2015, Ruuhijärvi \& Lindholm 2006) provided a complex ecohydrological interpretation of the original mire margin-expanse gradient of Sjörs (1948) (but see Rehell et al. 2019), according to which, mire-margin vegetation receives supplementary nutrients directly from mineral soil through a shallow peat layer in swamp forests (Bruchmoorigkeit; Tuomikoski 1942, Ruuhijärvi 1960, Eurola 1962), through flooding or surface water from snowmelt (Sumpfigkeit; Brandt 1948, Tuomikoski 1955, Ruuhijärvi 1960) and/or through rising of groundwater in spring fens (Quelligkeit; Ruuhijärvi 1960). Mire expanse vegetation is thus nutritionally self-sufficient, and supports Pinus sylvestris mires (Reisermoore; Ruuhijärvi 1960, Eurola 1962), treeless poor fens and bogs (Weissmoore; Ruuhijärvi 1960, Eurola 1962), as well as rich fens (Braunmoore; Ruuhijärvi 1960).
According to Havas (1961), sloping fens are fens (peatland) situated on sloping ground but he did not define the slope-angle range. His data reveal, however, that this range should be from $1^{\circ}$ to $12^{\circ}$. In more oceanic areas of Scandinavia slopes may exceed $20^{\circ}$ (Moen 1990, 1999, Joosten et al. 2017). Ruuhijärvi (1960), Havas (1961) and Eurola et al. (1984, 1995, 2015) regarded sloping fens as a topographic variant of aapa mires. Generally, sloping fens occur in mountainous areas with cool climate associated with hygric oceanity (Eurola \& Kaakinen 1982, Eurola et al. 1982, 1991). In central Europe, such fens are found only in areas with high precipitation in montane, subalpine and low alpine belts (Grünig 1994, Steiner 2005, Cubizolle \& Thebaud 2014, Dítě et al. 2015). In Scandinavia, they are common in mid-boreal to northern boreal zones and in low-alpine belts (Moen 1990, 1999, Rydin et al. 1999, Gunnarsson \& Löfroth 2014). In Finland, they occur in eastern (Havas 1961) and north-eastern parts of the country (Paasovaara 1986), while their occurrence further north in Lapland is largely unknown (but see Laitinen et al. 2011, Kaakinen et al. 2018). The southernmost sloping fens (North Karelia, southeastern Finland) have largely lost their natural state due to human activity (Kaakinen et al. 2018).

Havas (1961) was the first to include measurements of environmental variables in a vegetation survey of eastern Finnish sloping fens. He found that in sloping fens, temporal variation in water conditions affected the vegetation of lawns, and included the mire surface level and the poor-rich gradient, as well as the effects of mowing and grazing (Wiesenartigkeit) in his interpretation (see Moen et al. 2011). He however did not much consider differences among different parts of a single mire.

We re-analysed the data of Havas (1961) using NMDS ordination to reveal (1) gradients in plant community composition, and (2) their dependence on environmental variables and plant diversity. We also defined vegetation types using indicator species assemblages based on the gradient structure. Finally, we compared the classic mire-gradient interpretation with the approach in central Europe, and scrutinize similarities of plant communities between Scandi- 
Fig. 1. Studied area in eastern Finland with study localities classified a priori into the following topographic regions: $P=$ peripheral region, $\mathrm{NU}=$ northern uplands, $\mathrm{CHR}=$ central hill range, $\mathrm{SHR}=$ southern hill range (see Appendix 1). Most of the localities in SHR, CHR and $P$ are in the midboreal zone, and those in NU are in the northern boreal zone.

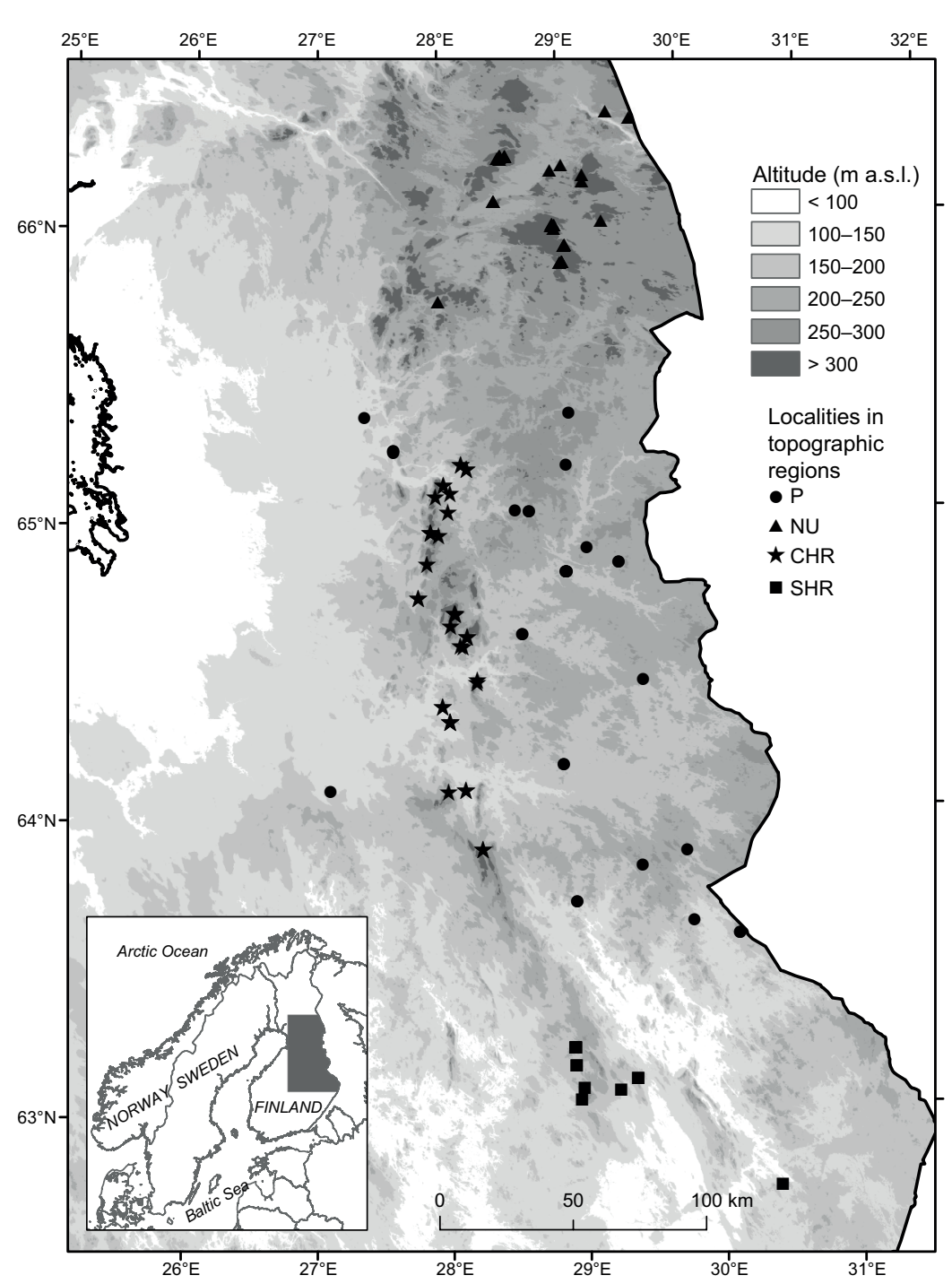

navian sloping fens and central European montane-subalpine-alpine fens.

\section{Study area, material and methods}

\section{Study area}

The studied area (Fig. 1 and Appendix 1) lies within the Fennosarmatian Precambrian bedrock block (Alalammi 1990) covered to different degrees by glacial deposits. It stretches from the mid-boreal to the north-boreal zone. In 19211960 , the annual mean temperatures ranged from ca. +2.5 to $0{ }^{\circ} \mathrm{C}$ and the effective temperature sum of the growing season from 750 to $1000{ }^{\circ} \mathrm{C}$ (Alalammi 1987). In the same period, annual precipitation and maximum snow depth in the forests were 600-750 mm (Alalammi 1987) and 65-90 cm, respectively. Climate conditions can be defined as thermally continental, but with hygric oceanity increasing towards higher elevations, where Picea abies forests with extensive snow damage almost exclusively prevail, and where sloping fens are also found (Eurola \& Kaakinen 1982, Eurola et al. 1982, 1991). Between 1847 and 2013, the mean annual temperature rose by ca. $2{ }^{\circ} \mathrm{C}$, and warming has 
accelerated after the 1960s (Mikkonen et al. 2015).

\section{Material}

\section{Nomenclature of plants and vegetation}

Nomenclature for vascular plants follows Hämet-Ahti et al. (1998), for bryophytes Ulvinen et al. (2002), and for lichens Stenroos et al. (2011). In the analyses, Scorpidium cossonii and $S$. revolvens were treated together, because the taxon Drepanocladus revolvens recognized by Havas (1962) includes these two species.

Our treatment of vegetation (species composition, ecology and climatic ranges) focused on the community level. The community names of the eastern Finnish sloping fens follow Havas (1961), and those of the Finnish mire site types follow Ruuhijärvi (1960: original names in German) and Eurola et al. (2015: names in English). The nomenclature of Scandinavian plant communities follows Sjörs (1946), Persson (1962) and Moen et al. (2011); that of central European communities, associations and alliances follows Hájek et al. (2005, 2006, 2008), Hájková et al. (2006), Sekulová et al. (2011), Conradi and Friedman (2013), and Peterka et al. (2014).

\section{Vegetation data}

We used all vegetation data of Havas (1961) except for site PP4 (rimpi vegetation), the location of which could not be confirmed. One vegetation sample generally included five $1-\mathrm{m}^{2}$ vegetation plots. Havas (1961) used the following cover scale (\%-cover): $1,3,5,7,10,20,30$, $40, \ldots, 100$. In his tables, cover estimates were given as medians. Species frequencies were estimated on the scale from 1 to 5 , standing for the number of plots in which the species was found. In sites with trees, Havas (1961) estimated the cover in $100-\mathrm{m}^{2}(10 \times 10 \mathrm{~m})$ squares. We used the median cover values as well as the additional species occurrences to include as much compositional information as possible. Additionally, he included the species that were found just outside the plots indicating them with ' + '. We included those with the cover value of $0.25 \%$.

\section{Geospatial and environmental data}

We determined approximate geographical coordinates and elevations above sea level of the sampling sites using the site descriptions given in Havas (1961). We first located each mire on a map, and then assigned the coordinates and elevation of its central point to all vegetation samples from this mire (Fig. 1). Thus, although the location data for all the samples within the site are the same, we considered it sufficient for regional-scale comparisons.

Water $\mathrm{pH}$ values for sample plots were taken from Havas (1961). The values for hummocklevel sites (Calluna vulgaris-Molinia caeruleaSphagnum fuscum community), and few other site types were lacking. Slope angle was first included but we decided to omit it, as it did not reveal any interpretable pattern.

The temperature and precipitation data were obtained from the Finnish Meteorological Institute. Using R package gstat (Gräler et al. 2016), we interpolated the averages of monthly precipitation and temperature to a $1 \times 1-\mathrm{km}$ grid using kriging, with covariates for lake density and elevation. Although elevation was included in the interpolation, the data for high elevations - above $200 \mathrm{~m}$ a.s.l. and $300 \mathrm{~m}$ a.s.l. in the southern and northern parts of the study area, respectively — were not available, hence the precipitation values may be underestimated.

In our analyses, we used mean annual temperature, mean annual temperature range, and annual precipitation sum.

\section{Methods}

\section{Sloping fen occurrence}

To establish a regional sub-division for the vegetation analysis, we used topographic regions (Fig. 1 and Appendix 1) instead of ordinary climate-phytogeographical zones of mire or forest vegetation. This was done because topography and elevation are significant factors for the veg- 
etation of poor fens and mesic heath forests in mid-boreal hilly areas (Eurola \& Kaakinen 1982, Eurola et al. 1991). The high-elevation areas were classified as the core regions of sloping fens, and the low-elevation areas around the core regions as the peripheral regions (see Appendix 1). Rough limits between the peripheral and core regions were at about $150 \mathrm{~m}$ a.s.l. and about $200 \mathrm{~m}$ a.s.l. in the southern and northern parts of the study area. The core and peripheral regions, however, were not defined by following exact contour lines but by grouping the mires studied by Havas (1960) into those on large forested hillareas and those around such areas.

\section{Ecological species groups}

We used ecological species groups based on the groups in Havas (1961) to aid the vegetation analysis interpretation (Appendix 2). We, however, added some species of contact habitats of boreal mires, occurring in the material, to describe the continuum from mires to other habitats. These species groups were representative for (1) flark-lawn-hummock-level gradient, (2) gradient along the unstable-stable water regime, (3) the poor-rich gradient, and the transitions to (4) forest vegetation (groups Hum-Pinus, HumPicea, Herb-Picea), (5) spring vegetation, and (6) meadow vegetation (see Appendix 1).

\section{Species richness}

The species richness for each vegetation sample was based on the data of Havas (1961). Although he included all species, he did not account for the area effect, thus species richness is informative of the communities only.

\section{Non-metric multidimensional scaling ordination (NMDS) analysis}

We used the NMDS ordination (Kruskal 1964, Faith et al. 1987) to reveal gradients in the plant communities. NMDS is an unconstrained ordination that condenses $n$-dimensional information of species matrix to $k$-dimensional ordination based on dissimilarities between samples. Thus, the ordination represents variation in composition of plant communities that can be compared to other measurements and attributes of the samples. For the measure of dissimilarity/distance in plant communities, we used the Bray-Curtis dissimilarity (Minchin et al. 1987). The NMDS axes are not uniquely defined, and any rotation of the solution will retain the same distances among the points in ordination. Thus, the solution can be so that the first axis covers most of the variation (Kruskal 1964), or the solution can be rotated so that the axes are optimally interpretable in ecological terms. We rotated the solution according to the most strongly correlated environmental variable $(\mathrm{pH})$ describing the main environmental gradient. Correlation of each measured environmental variable was assessed by fitting a firstdegree trend surface which is uniquely defined by its gradient, or the direction of the steepest change in the surface. In the ordination space this is shown by an arrow whose length indicates goodness of fit. For certain variables, we chose to use non-linear trend surfaces as isocline curves to better illustrate the relationship with ordination. These were obtained by fitting an isometric thin-plate spline for the environmental variable on ordination space (see https://cran.rproject.org/package=vegan). As the axes are not uniquely defined in NMDS, no correlations with the axes were calculated, but the fitted vector gives a rotation-invariant way of describing the goodness of solution in predicting the environmental variable.

The analyses were performed with $\mathrm{R}$ package vegan (https://cran.r-project.org/package=vegan).

\section{Formation and description of communities}

After several trial runs, we decided to use the original communities (Siedlungsgruppe) that were based on floristic similarities and differences (Havas 1961; Appendix 3). There were two reasons for that: (1) they appeared as distinct groups in the NMDS ordination, and (2) they compare to botanical Finnish mire site types (Ruuhijärvi 1960, Eurola 1962, Eurola \& Kaakinen 1978, Eurola et al. 1984, 1995, 2015) and to 
sloping-fen communities of the Central Scandes in Sweden (Sjörs 1946).

In the results, we present communities with the indicator species for gradients (based on NMDS). We used the mire species that Eurola et al. (2015) grouped regarding gradients as follows: (I) four classes of the poor-rich gradient (ombro-, oligo-, meso- and eutrophic), (II) three classes of mire surface levels (hummock level, intermediate level, flark level), and (III) six classes of the mire margin-expanse gradient. The mire margin categories included species indicating effects of (1) groundwater from springs, (2) surface water, and (3) mineral soil and forest. Mire-expanse categories included groups of species typical for (1) Pinus sylvestris forest and hummock-level bogs, (2) poor fens and hollow to lawn level bogs, and (3) rich fens.

For the oligotrophic-eutrophic gradient of Eurola et al. (2015), we used the poor-rich classification of Sjörs (1948, 1952), Persson (1962), and Sjörs and Gunnarsson (2002):

- extremely poor fens had at least one indicator of weak minerotrophy (oligotrophy or oligomesotrophy); moderately poor fens had at least one indicator of stronger minerotrophy (mesotrophy and often additionally mesoeutrophy);

- intermediate fens had several indicators of mesotrophy and meso-eutrophy (see Ruuhijärvi 1960 for the description of Molinia Braunmoore-Weissmoore), with rich-fen species (eutrophic) occasionally present;

- rich fens were dominated either by minerotrophic Sphagnum spp. (mainly S. warnstorfii with the rich-fen proper indicator Tomentypnum nitens), or by rich-fen brown-mosses of various mire surface levels and various margin-expanse status.

We based our mire surface-level classification (flark, lawn, and hummock levels) on dominating (indicator) species. Regarding the water regime, we applied the following classification: unstable water regime evidenced by the Molinia species group of Havas (1861), and disturbance indicators (Störzeiger) of Dierssen (1982) (Carex nigra, Agrostis canina, etc.); and stable water regime evidenced by Eriophorum vaginatum species group of Havas (1961), the bulk of species in the Menyanthes species group, the hummock-level species, and the species indicating groundwater effect (our Paludella group and Sphagnum warnstorfi). The stable water regime indicator species do not tolerate severe seasonal drying of the peat surface (Laitinen 2008).

Mire margin-expanse vegetation classification was based on the presence/absence of mire-margin indicator species, reflecting either mineral-soil effect (spruce-mire effect according to Eurola et al. 2015; Bruchmoorigkeit in Ruuhijärvi 1960, Eurola 1962), surface-water effect (Sumpfigkeit; Brandt 1948, Tuomikoski 1955, Ruuhijärvi 1960), and/or groundwater effect (Quelligkeit; Ruuhijärvi 1960).

\section{Results}

\section{NMDS analysis}

\section{Environmental gradients}

Water $\mathrm{pH}$ (NMDS 1) was the most significant variable, explaining $69 \%$ of the vegetation variation presented by the ordination (Fig. 2). It ranged from 4.0 (community 7 ) to $>6.4$ (subcommunity 5.2). Of the climatic variables (NMDS 2), mean annual precipitation was the most significant explaining $24 \%$ of the vegetation variation presented in the ordination, followed by mean annual temperature $(9 \%)$, and annual average temperature range $(8 \%)$. Slope angle (exposition) effect was negligible (not shown).

\section{Gradients by indicator species groups and communities}

NMDS 1, NMDS 2 and NMDS 3 divided indicator species groups (Appendix 2) in the ordinations (Figs. 3 and 4). The poor-rich gradient (L-Rich, Campylium stellatum group) approximately followed the $\mathrm{pH}$ gradient along NMDS 1 (Fig. 3).

NMDS 2 separated hummock-level species (Hum-Pinus, Empetrum group) and flark-level species (Flark, Menyanthes group) (Fig. 3), as 
Fig. 2. NMDS ordination; circles = sample plots, numbers $=$ communities (see Appendix 3), vectors $=\mathrm{pH}$, precipitation, average temperature, temperature range. Ellipses show standard deviations for the communities. The result was rotated to align $\mathrm{pH}$ with axis (NMDS) 1.

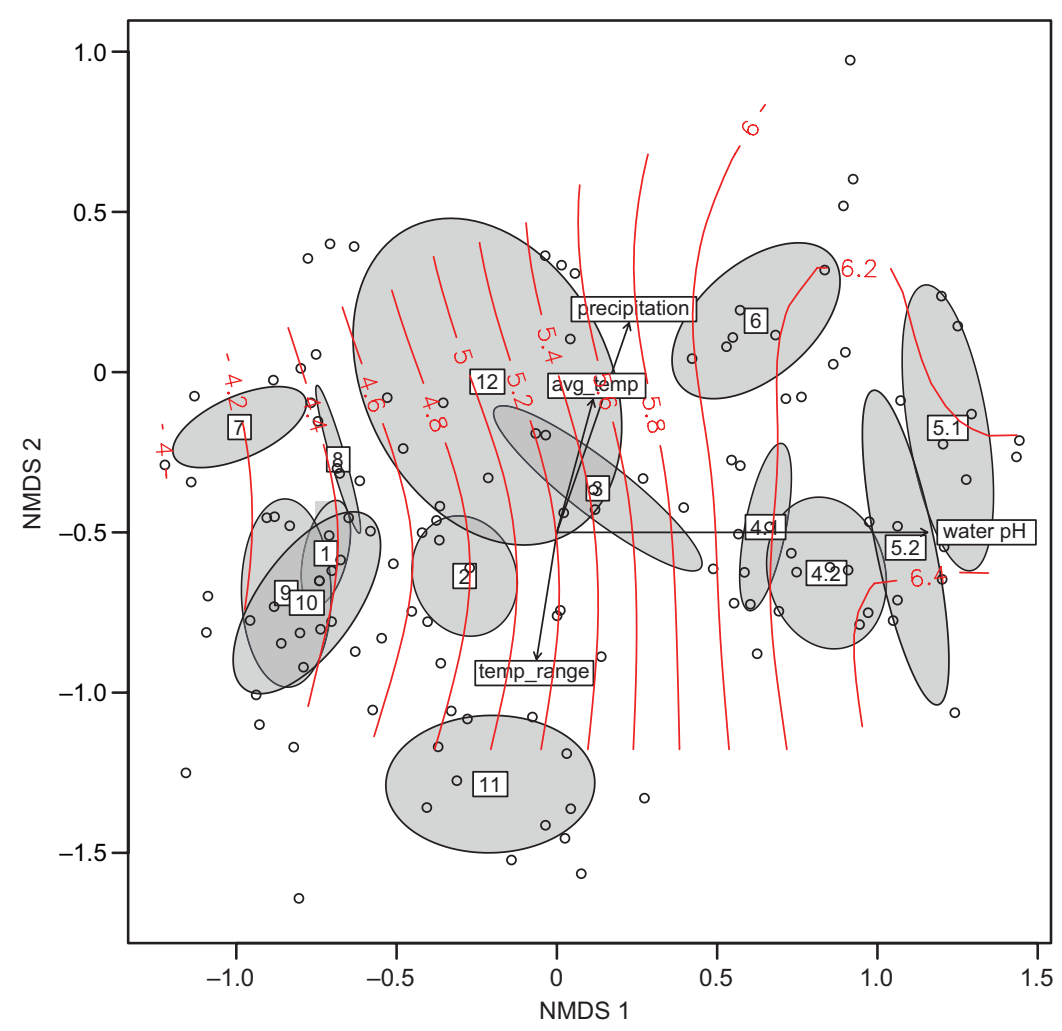

well as the hummock-level communities $(11,10$, 9), lawn communities $(7,8,1,2,3,4,5$; except 6 separated along NMDS 3, see Fig. 4), and flark community (12).

NMDS 3 separated species in the L-Unstable group (Molinia group), as well as in HumPicea (Carex globularis group) and Herb-Picea (Filipendula group) groups (Fig. 4). There was an indication of the gradient from unstable (bottom part of Fig. 4) to stable (top part of Fig. 4) water regimes along NMDS 3. NMDS 2 and NMDS 3 best separated the species groups Spring (Paludella group) and Meadow (Festuca group) (Appendix 2).

Extremely poor fen communities $(7,8,1$, $9,10)$ formed a loose cluster related to low pH (Figs. 2, 3 and 4). They also were very clearly positioned along NMDS 3, representing unstable-stable gradient. Moderately poor fen communities $(12,2,11)$ were positioned along NMDS 2 (mire surface level gradient), while the only intermediate fen community (3) had a central position in the ordination. Rich mire margin fen community (6) was separated from the other communities in all dimensions.

Sub-communities 4.1, 4.2, 5.1 and 5.2 formed a tight cluster along NMDS 1, with some separation along NMDS 3: mire margin-expanse gradient was evident, while the stable-unstable gradient was less so (Fig. 4). They also slightly differed along NMDS 1 (poor-rich gradient; Figs. 2 and 3)

\section{Gradient structure by topographic regions}

Vegetation sample plots, grouped according to the four topographic regions, largely overlapped in the NMDS ordination (Fig. 5). The centres of regional groups, however, formed a series nearly along the poor-rich gradient (NMDS 1). They formed a continuum from the peripheral region (P) - largest proportion of poor-fen vegetation - to northern uplands (NU), to central hill range (CHR), and to the southern hill range (SHR) - 

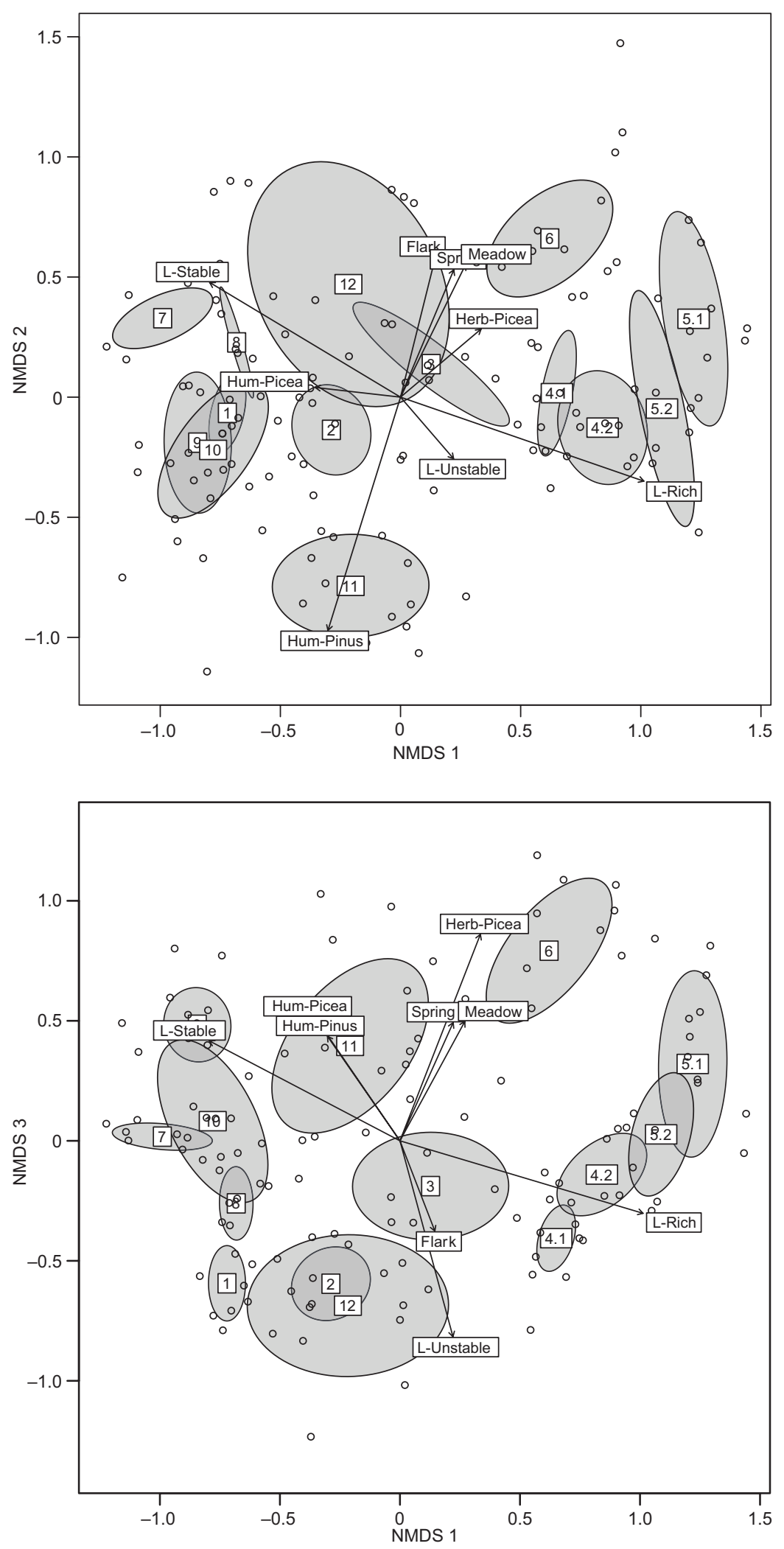

Fig. 3. NMDS ordination; circles $=$ sample plots, numbers $=$ communities (see Appendix 3), vectors $=$ indicator species groups (see Appendix 2). Ellipses show standard deviations for the communities. The result was rotated to align $\mathrm{pH}$ with axis (NMDS) 1.

Fig. 4. NMDS ordination; circles $=$ sample plots, numbers $=$ communities (see Appendix 3), vectors $=$ indicator species groups (see Appendix 2). Ellipses show standard deviations for the communities. The result was rotated to align $\mathrm{pH}$ with axis (NMDS) 1. 
Fig. 5. Plots grouped according to topographic regions; $\mathrm{P}=$ peripheral region, $\mathrm{NU}=$ northern uplands, $\mathrm{CHR}=$ central hill range, $\mathrm{SHR}=$ southern hill range. For topographic regions, see Appendix 1.

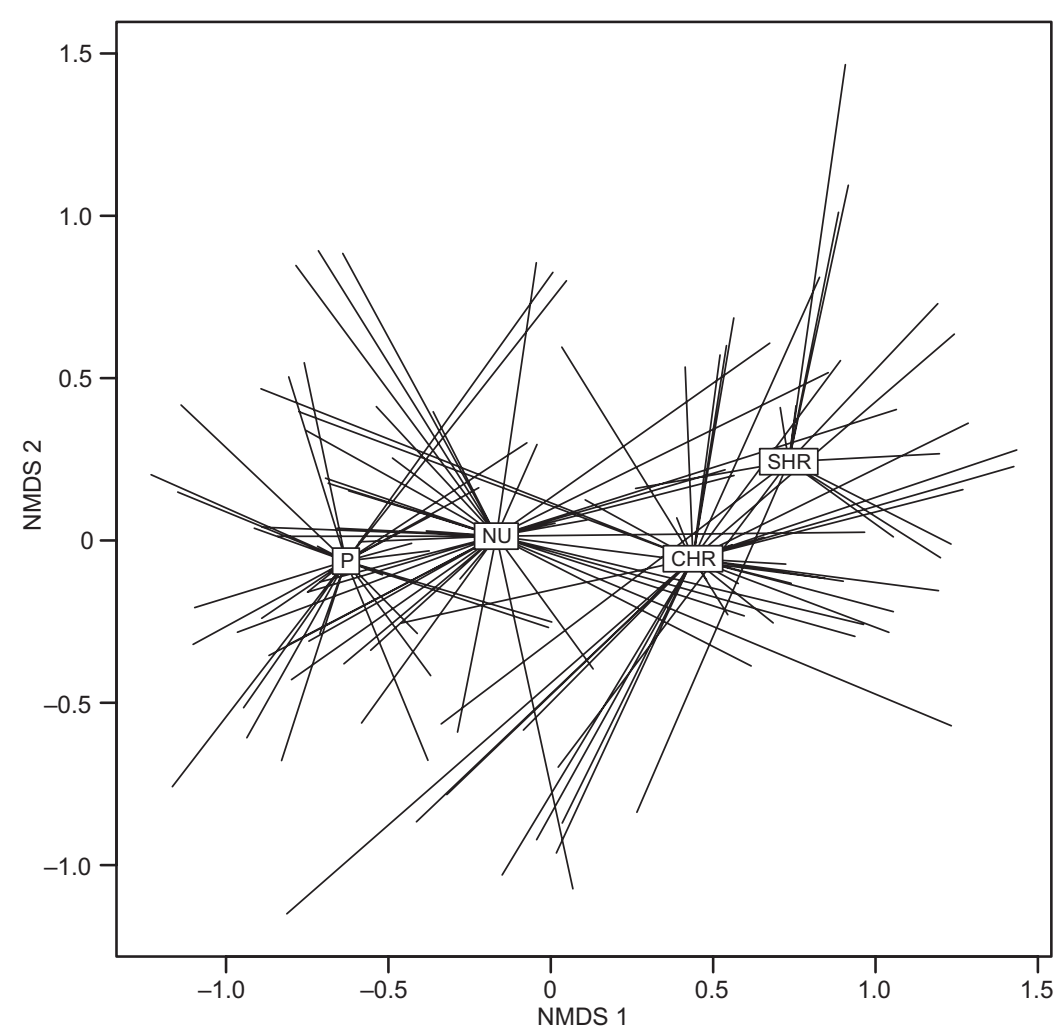

smallest proportion of poor-fen vegetation. The three high-elevation topographic regions were arranged from north to south as follows: NU, $\mathrm{CHR}$, and SHR, reflecting climatic variation.

\section{Species richness}

Species richness varied from $\sim 10$ to $>45$ species per vegetation sample plot, largely increasing along NMDS 1, and the poor-rich gradient. The lowest species richness was in community 7 with the lowest $\mathrm{pH}$ (Fig. 6). The maximum species richness, however, was recorded not in plots with maximum $\mathrm{pH}$ but in the mire margin communities of rich lawn fens (sub-communities 5.1 and 5.2), and in the weakly rich mire margin community 6 (Fig. 7). Community 1 was one with the lowest species richness (Fig. 7). Also the wettest habitats (community 12) included plots with very low species richness (Fig. 7).

Species richness was also associated with the topographic regions, as it clearly increased from the peripheral region $(\mathrm{P})$ towards the core areas of high elevation, and towards the south (from NU to CHR to SHR) (Fig. 5).

\section{Plant community types}

In this chapter, the fens are described in the following order: extremely poor fens (communities $7,8,1,9,10)$, moderately poor fens (communities 12, 2, 11), intermediate fens (community 3 ), rich fens (communities 6, 4 (4.1, 4.2), 5 (5.1, 5.2)).

\section{Extremely poor lawn fens}

Carex pauciflora was the most frequent extremely poor-fen indicator in all communities. Lawn indicators were the dominants Trichophorum cespitosum, Eriophorum vaginatum, Sphagnum compactum or $S$. angustifolium (the latter two at different sample plots), and S. papillosum. Mire margin indicators were lacking. 

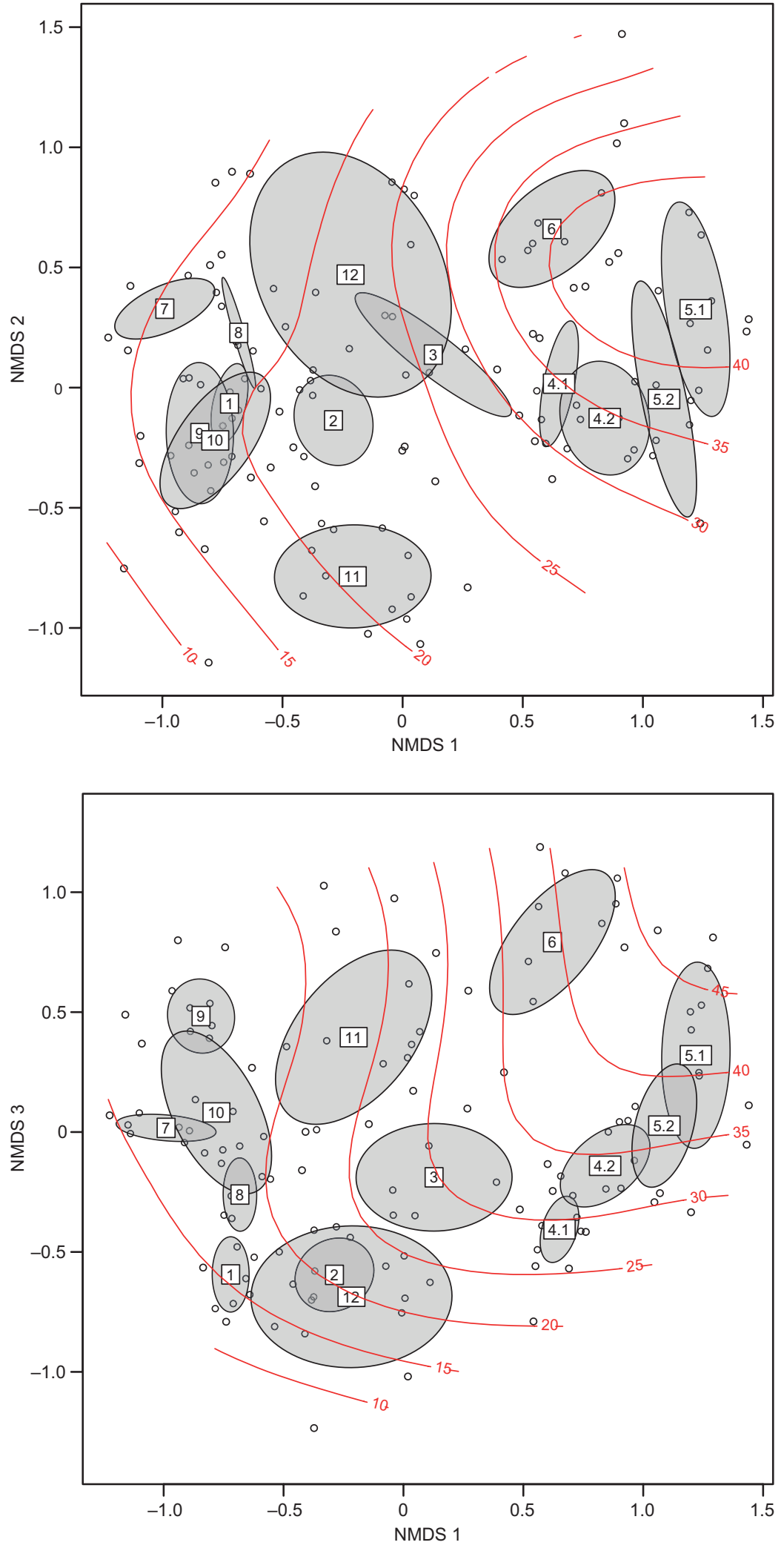

Fig. 6. Grouping of plots (circles), communities (numbers), and average species richness. The ellipses show the standard deviations for the communities. For community names, see Appendix 3.

Fig. 7. Grouping of plots (circles), communities (numbers), and average species richness. The ellipses show standard deviations for the communities. For community names, see Appendix 3. 
Fig. 8. Latitude-elevation ranges of communities. For community names, see Appendix 3.

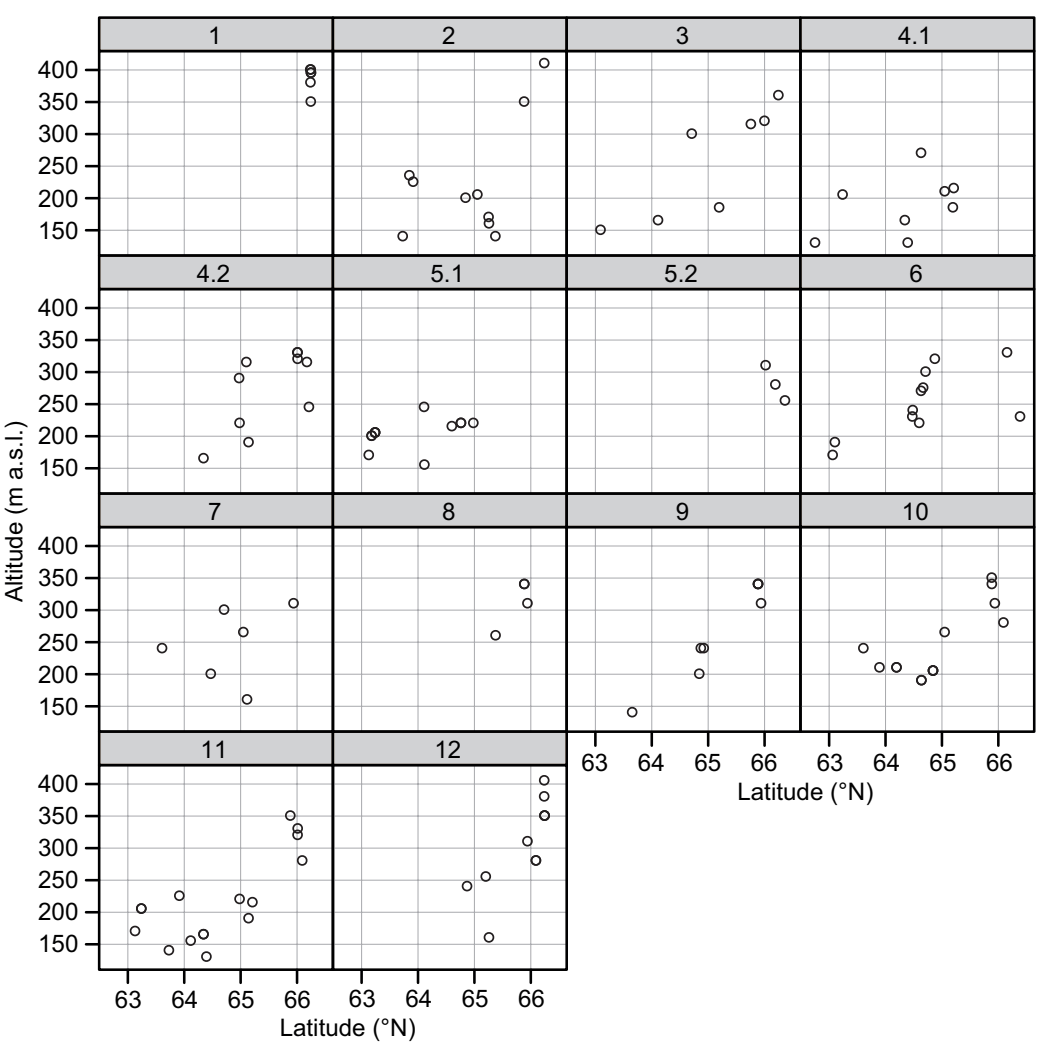

Community 7 (Betula nana-Eriophorum vaginatum-Sphagnum angustifolium community; Figs. 3 and 4): widespread in the study area within an elevation range of 150-300 m a.s.l. (Fig. 8). Additional extremely poor-fen indicators were Menyanthes trifoliata (ST water regime) and Carex rostrata. Lawn indicators were the dominants Eriophorum vaginatum and Sphagnum angustifolium. Betula nana was most abundant in this community among lawn fens. Central indicators of unstable water regime (Trichophorum cespitosum, Sphagnum compactum) were lacking.

Community 8 (Eriophorum vaginatum-Sphagnum lindbergii-S. russowii community; Fig. 8): northern, occurring at high elevations (250-350 m a.s.1.). Extremely poorfen indicators were Sphagnum papillosum, S. fallax and Carex lasiocarpa. Lawn indicators Trichophorum cespitosum, Eriophorum vaginatum, and Sphagnum papillosum were constant as were Andromeda polifolia and Betula nana. Menyanthes trifoliata (stable water regime) was absent.
Community 1 (Trichophorum cespitosumSphagnum compactum-Ptilidium ciliare community; Fig. 8): it represented northern vegetation of high elevations $(350-400 \mathrm{~m}$ a.s.1.). Extremely poor-fen indicators were Eriophorum angustifolium, Carex rostrata and C. lasiocarpa; their frequencies, however, were low. Lawn indicators were the dominants Trichophorum cespitosum and Sphagnum compactum. Sphagnum tenellum was frequent, and Ptilidium ciliare and some dwarf shrubs were constant (Andromeda polifolia, Betula nana, Empetrum nigrum s. lato, Vaccinium oxycoccos, V. uliginosum). All abundant species were unstable-waterregime indicators, while stable-water-regime indicators were almost lacking.

\section{Mire margin and expanse vegetation of extremely poor hummock-level mires}

Minerotrophic hummock-level vegetation was dominated by Carex globularis or dwarf shrubs 
and sparse stands of trees (Pinus sylvestris or Picea abies). Dominants in the moss layer were primarily hummock-level species (Sphagnum fuscum, S. russowii, S. angustifolium).

Community 9 (Carex globularis-Sphagnum fuscum-S. russowii community; Figs. 3 and 4): represented mire margin vegetation, as it included at least small amounts of mire margin indicators of mineral-soil effect (Picea abies, Carex globularis, Equisetum sylvaticum, Polytrichum commune). Carex globularis, Sphagnum fuscum and S. angustifolium were dominants. Wide latitudinal distribution, elevation range 130-350 $\mathrm{m}$ a.s.l. (Fig. 8).

Community 10 (Vaccinium uliginosum-Sphagnum fuscum-S. angustifolium community): represented mire expanse vegetation with no mire-margin indicators. It included small amounts of indicators of extremely poor fens (Carex lasiocarpa, C. pauciflora, C. rostrata). Dominant species were Vaccinium uliginosum, Sphagnum fuscum, $S$. angustifolium and Empetrum nigrum s. lato. Additional dominants were Chamaedaphne calyculata (not in the northernmost parts), Trichophorum cespitosum, and occasionally Sphagnum magellanicum or S. balticum. Wide latitudinal distribution, elevation range 180-350 m a.s.l. (Fig. 8).

\section{Flark fens (moderately poor fens)}

Community 12 (flark community): represented mire expanse vegetation with varying poorrich status and variation from carpet to mudbottom (Figs. 3 and 4). The elevation range was the greatest among all communities (150-400 m a.s.1.) (Fig. 8). Carex rostrataSphagnum lindbergii carpet represented northern extremely poor fen. In rich flark fens, e.g. Eriophorum latifolium, Scorpidium revolvens, and Aneura pinquis were present.

\section{Moderately poor lawn fens}

Community 2 (Molinia caerulea-Trichopho- rum cespitosum-Sphagnum compactum-S papillosum community): Molinia caerulea was the only constant moderately poor fen indicator (Figs. 3 and 4). Trientalis europaea occurred in almost half of the plots. There were no or only few intermediate fen indicators per plot, most frequent was Loeskpynum badium, while the others were Selaginella selaginoides, Pinguicula vulgaris, Sphagnum subfulvum, S. warnstorfii and Tofieldia pusilla. Lawn indicators were the dominants Trichophorum cespitosum, Sphagnum papillosum, and S. compactum. Specific mire-margin indicators were lacking. The dominants belonged to the indicators of unstable water regime (Molinia group) but also a central indicator of stable water regime (Sphagnum fuscum) was infrequently present. Wide distribution, elevation range $150-400 \mathrm{~m}$ a.s.l. (Fig. 8).

\section{Fen hummocks (moderately poor fens)}

Community 11 (Calluna vulgaris-Molinia caerulea-Sphagnum fuscum community): occurred on hummocks of sloping fens (Figs. 3 and 4). The poor-rich status varied markedly according to the presence or absence of moderately poor fen indicators (Molinia caerulea, Solidago virgaurea, Trientalis europaea), intermediate fen indicators (Carex vaginata, Trichophorum alpinum, Potentilla erecta, Selaginella selaginoides, Tofieldia pusilla, Bartsia alpina), and the exceptional presence of rich fen indicators (Carex flava, Salix myrsi-nites, Eriophorum latifolium, Carex panicea, Equisetum variegatum, Cinclidium stygium). The indicators of hummock level included the dominants Juniperus communis, Calluna vulgaris, Empetrum nigrum s. lato, Sphagnum fuscum, Pleurozium schreberi, Hylocomium splendens and Cladonia rangife-rina. There was additionally minor variation according to the presence or absence of mire margin species (Angelica sylvestris, Geranium sylvaticum, Convallaria majalis, Rubus saxatilis, Helodium blandowii). Wide distribution, elevation range 120-350 m a.s.l. (Fig. 8). 


\section{Intermediate fens}

Community 3 (Molinia caerulea-Trichophorum cespitosum-Sphagnum warnstorfii community): represented intermediate lawn fens. Moderately poor fen indicator Molinia caeurulea was constant, Carex echinata was nearly constant, and Viola epipsila occurred several times. In most plots several intermediate fen indicators were present. Sphagnum warnstorfii, Selaginella selaginoides and Paludella squarrosa were nearly constant. Other frequent intermediate fen indicators were Trichophorum alpinum, Sphagnum subfulvum and S. subsecundum. Also Tofieldia pusilla was relatively frequent. Carex dioica, Potentilla erecta, Parnassia palustris, Bartsia alpina, Loeskypnum badium and Sphagnum teres were relatively rare. Exceptionally, some of the plots had some rich fen species with a low cover value (Carex flava, Eriophorum latifolium, Carex panicea, Campylium stellatum or Scorpidium scorpioides). Mire expanse species (Molinia, Trichophorum cespitosum, Sphagnum subfulvum, S. papillosum) mostly dominated. Mire margin species were less common (Sphagnum teres), apart from Sphagnum warnstorfii. Lawn indicators present as dominants were Trichophorum cespitosum, variably Sphagnum subfulvum, S. papillosum and S. angustifolium. The higher-lawn indicator Sphagnum warnstorfii was also present. The community represented heterogeneous mire expanse vegetation, as ecologically different Sphagnum species (Sphagnum angustifolium, S. papillosum, S. subfulvum, S. subsecundum, $S$. warnstorfii). Species of stable water regime (Sphagnum warnstorfii) dominated in plots. Also Trichophorum cespitosum indicating unstable water regime was found among the dominants. Wide distribution, elevation range 150-350 $\mathrm{m}$ a.s.l. (Fig. 8).

\section{Mire margin vegetation of rich lawn fens}

Community 6 (Carex magellanica-Filipendula ulmaria-Sphagnum warnstorfii community) represented higher lawn vegetation (cf. com- munities 5 and 4 below). Extremely poor fen species Carex magellanica and moderately poor fen species Carex echinata, Solidago virgaurea and Trientalis europea were frequent. Intermediate fen indicator Selaginella selaginoides was constant. Few rich fen indicators were present, most frequent among them were Eriophorum latifolium and Tomentypnum nitens. The dominant Sphagnum warnstorfii was a prominent indicator of higher lawn, while less frequent and subordinate Tomentypnun nitens and Sphagnum angustifolium indicated the same surface level. Contrary to the intermediate lawn fen community 3 , typical mire expanse vascular plants of lawns (Trichophorum cespitosum, Molinia caerulea) were rare and typical mire-expanse Sphagnum species of lawns (S. subfulvum, S. papillosum) were lacking. Mire margin species, especially indicating groundwater and mineral-soil effects, were numerous. They included Salix phylicifolia, Luzula sudetica, Angelica sylvestris, Crepis paludosa, Filipendula ulmaria, Geranium sylvaticum, Bistorta vivipara, Phleum alpinum, Bryum pseudotriquetrum, Plagiomnium ellipticum, and Paludella squarrosa. Dominant species indicated stable water regime (Sphagnum warnstorfii). Wide distribution, elevation range 170-330 $\mathrm{m}$ a.s.l. (Fig. 8).

Community 5 (Carex flava-Filipendula ulmaria-Campylium stellatum community; (Figs. 3 and 4) represented slightly lower lawn related to community 6 and mire margin vegetation with Trichophorum cespitosum almost absent and with abundant mire margin species. Molinia caerulea was frequent.

Sub-community 5.1 (C. nigra sub-community): represented southern mire margin vegetation occurring at low elevations (150-250 m a.s.1.) (Fig. 8). Constant rich-fen indicators included Carex flava, Eriophorum latifolium, Campylium stellatum and Scorpidium revolvens $s$. lato. Lawn indicators included the dominant moss species (Campylium stellatum, Scorpidium revolvens s. lato). Frequent mire margin species indicating surface-water, groundwater and mineral-soil effects were numerous. They included Carex nigra, $C$. canescens, Equisetum palustre, Angelica 
sylvestris, Crepis paludosa, Filipendula ulmaria, Geranium sylvaticum, Pedicularis palustris, Bistorta vivipara, Rubus arcticus, and Bryum pseudotriquetrum. Carex nigra appeared as an indicator of the unstable water regime.

Sub-community 5.2 (Saussurea alpina subcommunity): represented clearly northern mire margin vegetation at intermediate elevations (250-300 $\mathrm{m}$ a.s.l.) (Fig. 8) in the Kuusamo area. Constant rich-fen indicators were Pinguicula alpina, Cinclidium stygium, Scorpidium revolvens s. lato and Aneura pinguis. Lawn indicators were the dominants Campylium stellatum and Scorpidium revolvens $s$. lato. Frequent mire margin species (including Pinguicula alpina, Saussurea alpina, Equisetum fluviatile, Angelica sylvestris, Crepis paludosa) were primarily indicators of groundwater and mineral-soil effects. Based on the dominants, stable water regime was evident.

\section{Mire expanse vegetation of rich lawn fens}

Community 4 (Carex flava-Trichophorum cespitosum-Campylium stellatum community): represented lower lawn mire expanse vegetation with Trichophorum cespitosum as a dominant, while mire margin species were scarce. Molinia caerulea was constant. The dominants were indicators of unstable water regime, while some indicators of stable water regime also occurred (Menyanthes trifoliata, Sphagnum warnstorfii).

Sub-community 4.1 (Loeskypnum badium subcommunity): represented slightly southern mire expanse vegetation and occurred at relatively low elevations (120-270 m a.s.1.) (Fig. 8). Intermediate-fen species Loeskypnum badium was constant, as well as rich-fen indicators Carex flava, Eriophorum latifolium and Campylium stellatum. Lawn indicators were the dominants Trichophorum cespitosum and Campylium stellatum.

Sub-community 4.2 (Pseudocalliergon trifarium sub-community): represented slightly northern mire expanse vegetation occurring at slightly higher elevations (170-330 m a.s.1.) (Fig. 8). Constant rich-fen indicators were the same as in sub-community 4.1., but additionally Pseudocalliergon trifarium was frequent. Intermediate fen species Loeskypnum badium was nearly absent. Extremely rich fen indicator Catoscopium nigritum was abundant in one plot.

\section{Discussion}

\section{Gradient structure and gradients of different scale and significance}

A three-dimensional vegetation gradient structure in eastern Finnish sloping fens revealed in this study resembles the three-gradient structures of Sjörs (1948), Ruuhijärvi (1960) and Persson (1962). Environmental variables $(\mathrm{pH}$, temperature, precipitation), however, supported separation along only two dimensions in the ordination, and only few species groups were separated along the third dimension. The poor-rich gradient associated with $\mathrm{pH}$ formed the first dimension in the NMDS ordination. Increasing evidence shows that this gradient, related to $\mathrm{pH}$ (Tahvanainen 2004), or to $\mathrm{pH}$ and base cations (Sjörs \& Gunnarsson 2002, Hajek et al. 2006), is the main gradient in fens (Sjörs 1948, 1952, Hájek et al. 2006, Peterka et al. 2017). In our study the poor-rich gradient was also associated with the topographic regions that formed a continuum in the ordination, with differences in the abundance of poor and rich fen vegetation among regions differing in bedrock. Thus, it seems that the type of bedrock affects variation in water chemistry and vegetation in the sloping fens of eastern Finland (see Tahvanainen 2004). A considerable proportion of rich fens (Braunmoore; Ruuhijärvi 1960) in eastern Finland (Havas 1961), may be due to the prevalence of mafic and calcareous bedrock in hill ranges in northwestern part of Northern Karelia, western part of Kainuu and northeastern part of Kuusamo uplands (Simonen 1987). Sjörs (1946) recorded a greater proportion of poor to intermediate fens on siliceous bedrock in the Central Scandes in Sweden.

A gradient along mire surface levels was associated with NMDS, although it was not par- 
ticularly distinct, as there is less flark-level (wet surfaces) vegetation in sloping fens (Sjörs 1946, Persson 1962, Havas 1961) than in aapa mires (Ruuhijärvi 1960). The surface levels in boreal aapa mires are visible in aerial photos as dark flarks with open water, and lighter (mostly lawn level) belts where lawn and hummock levels mostly prevail (Laitinen et al. 2005, 2008a). Ruuhijärvi (1960) found a relationship between large-scale topographic patterns and compositional gradient of mire surface levels. In boreal areas, the surface level gradient is not associated with $\mathrm{pH}$ or fertility (see the discussion and references in Hájek et al. 2006). Hájková et al. (2004) found that water level is an important factor explaining within-site (small-scale) vegetation heterogeneity in the Carpathian fens. Small-scale variation in surface levels is also true for boreal mires (Tahvanainen \& Tuomaala 2003), but it reflects the larger-scale surface patterns, which justifies its use in vegetation classification (Sjörs 1948, Ruuhijärvi 1960, Persson 1962, Eurola 1962). It should, however, be pointed out that sample plot sizes in studies carried out in Finland and in Scandinavia were too small $\left(1 \mathrm{~m}^{2}\right.$ and $0.25 \mathrm{~m}^{2}$, respectively) (Pakarinen 1995), just in order to capture small-scale differences in mire surface levels. However, also using larger phytosociological relevés, Hájek et al. (2005) interpreted the 'succession-related moisture gradient' as the major compositional gradient in subalpine-spring fens in the Vitosha Mountains in Bulgaria. Thus the mire surface level, as we call it here, is one of the important compositional gradients in fens across Europe (Moen 1990, Økland et al. 2001, Vanderpuye et al. 2002).

In the NMDS ordination, water regime stability formed the third dimension. Although Sjörs (1946) did not recognize this gradient in his sloping fen study in the oceanic Central Scandes, he found that sloping fens generally have certain features (high decomposition rate of the surface peat) that are associated with greater water level fluctuations (Sjörs 1948). Auer (1922), Havas (1961), Laitinen (2008) and Laitinen et al. (2008a, 2008b) emphasised the effect of seasonal peat-surface drying on peat humification, while Havas (1961) first specifically stressed the two extremes in the stability gradient although his interpretation rests on water-table measure- ments made at six different sites during one growing season (see Havas 1961: fig. 112). The prevalently unstable water regime of sloping fens (Sjörs 1946, Havas 1961, Moen 1990) sets them apart from peatlands that more commonly have a stable water regime (Zoltai \& Vitt 1995). In our analysis the stable-to-unstable and the miremargin-to-expanse gradients were connected and partly associated with the same ordination dimension (NMDS 3). Unstable water regime was mainly associated with mire expanse vegetation, while stable water regime was mainly associated with mire margin vegetation. Hydrological patterns in sloping fens partly explain the association between mire margin vegetation and stable water regime. In upper marginal parts of sloping fens, rising groundwater (Quelligkeit; Ruuhijärvi 1960) may mitigate seasonal drought (Havas 1961), while in the central parts of sloping fens with mire expanse vegetation, there is no such effect. Since runoff threshold is generally low due to existing slope, the central parts tend to dry out. In the much larger central parts of aapa mires, however, mire expanse vegetation under normal stable water regime largely prevails, as their flark-string system retains water and maintains high runoff threshold (Laitinen et al. 2005, 2008a). In sloping fens, the hummock Sphagnum species, especially $S$. fuscum, retain water and maintain a stable peat-moisture level (Rydin 1985), and because of that, in our study the hummock-level communities $(9,10,11)$ dominated by $S$. fuscum had stable water regime.

Mire margin to expanse gradient (inflow of nutrients vs. self-sufficiency; Eurola et al. 1984, Eurola \& Huttunen 2006, etc.) at least partly seems to correspond to the fertility gradient of Hájek et al. (2006) which is based on the abundance of nutrient-demanding herbs and grasses (Hájek et al. 2006). In addition to the Filipendula (Herb-Picea) species group (mire margin species of moist herb-rich forests), in our analysis we also used the Festuca (Meadow) species group to reveal historical anthropogenic effects. After the cessation of haymaking and grazing in the 1950s, a large number of meadow species was a special feature in eastern Finnish sloping fens, as the cessation paradoxically increased the number of those species (Moen 1990, Moen et al. 2011, Hajek et al. 2006). Meadow species 
are typical of the fens of the nemoral zone in mountainous areas, where the gradient is clearly different from the poor-rich one (Hájek et al. 2006, Jiménez-Alfaro et al. 2013). This was also true in the boreal eastern Finnish sloping fens, although the meadow species (Wiesenartigkeit; Havas 1961) formed only a minor gradient among mire margin communities of rich fens. Fertility or meadow gradient seems to be of minor importance in boreal Fennoscandian mires, as classified by Økland et al. (2001).

Temperature and precipitation, varying from south to north, were associated with NMDS 2, separating mire surface levels. Flark fens (community 12 ) represent northern vegetation among the communities of eastern Finnish sloping fens (Havas 1961) (Fig. 8). Northerly location of flark fens is associated with Finnish aapa mires, and with the effect of spring floods from melting of snow in those areas (Ruuhijärvi 1960, Laitinen et al. 2017). Additionally in sloping fens, poor fens tended to be less common towards the south (Fig. 5), as in the south where elevations are generally lower, the climate is not oceanic enough for the formation of sloping fens (see Eurola \& Kaakinen 1982), except at sites with groundwater discharge and thus higher poor-rich status.

\section{Species richness and environmental constraints}

In the eastern Finnish sloping fens, species richness was positively related to the poor-rich and mire-expanse-to-margin gradient, and negatively to mire surface level. In other words, an increase in wetness resulted in a decrease in species richness, as was also found by Laitinen et al. (2017) for northern Finnish boreal wetland habitats, and by Hájek et al. (2005) for subalpine fens in the Vitosha Mountains, Bulgaria. Additionally, species richness was negatively related to stable-to-unstable water-regime gradient (water regime instability decreased species richness). It is remarkable that the maximum richness in the eastern Finnish sloping fens did not coincide with the highest $\mathrm{pH}$ but was found in communities with meadow species (Festuca group), spring-fen species (Paludella group), and spe- cies of herb-rich forests and herb-rich Picea abies mires (Filipendula group). In central Norwegian fens, the species richness was similarly highest ( $>50$ species) in a shrub-dominated fen margin of Sphagno-Tomentypnion (Moen et al. 2011), as it was in rich fens in central Europe (Hájek et al. 2006). Hájková and Hájek (2003) reported that in the flysch zone in the West Carpathians, communities transitional between fens and grasslands belong to the most species-rich vegetation types. We found that the increase in $\mathrm{pH}$ (to some degree), as well as in nutrient level (fertility) increased species richness, while extreme water conditions (constantly too wet/ seasonally too dry) reduced it.

\section{Communities in different regions and climates}

\section{Eastern Finland and Scandinavia}

Most communities in the eastern Finnish sloping fens were widely distributed within the area (Fig. 8). However, the two sub-communities (5.1 and 5.2) in the Carex flava-Filipendula ulmariaCampylium stellatum community were clearly arranged in the south-north direction. The Carex nigra sub-community (5.1) represented southern (mid-boreal) vegetation of lower elevations, not occurring in the northern boreal area, while the Saussurea alpina sub-community (5.2) represented northern boreal mid-elevation vegetation of the Kuusamo area (Ruuhijärvi 1960, Söyrinki et al. 1977), not occurring in the mid-boreal area.

The Trichophorum cespitosum-Sphagnum compactum-Ptilidium ciliare community (1) was restricted to the highest elevations (350$400 \mathrm{~m}$ a.s.1.), and it may be viewed as indicating the highest possible hygric oceanity (but thermal continentality) among the eastern Finnish sloping-fen communities (see Eurola \& Kaakinen 1982, Eurola et al. 1982, 1991, Paasovaara 1986). Sphagnum compactum Weissmoore (Ruuhijärvi 1960) were less oceanic, found in slightly sloping fens at lower elevations. The Trichophorum cespitosum-Sphagnum compactum community was found even in flat lowland aapa-mire peripheries. The latter two communities differed from the community of oceanic 
highlands (community 1 ) at least in lacking Ptilidium ciliare, an indicator of hygric oceanity in lawn fen vegetation (Eurola \& Kaakinen 1982). Additionally, the Eriophorum vaginatum-Sphagnum lindbergii-S. russowii community (community 8) occurred at relatively high elevations ( $>250 \mathrm{~m}$ a.s.1.) in sloping fens. This is exactly the elevation above which certain common treed-mire vegetation features of hygric oceanity (lack of Chamaedaphne calyculata and scarcity of Ledum palustre) appear in the mid-boreal part of our study area. The Saussurea alpina subcommunity (5.2) occurred above $250 \mathrm{~m}$ a.s.l. It, however, was found only in the Kuusamo area, most of which is located above $250 \mathrm{~m}$ a.s.l. Eurola and Kaakinen (1982) discussed the effect of increasing elevation and hygric oceanity only on the vegetation of poor rather than rich fens.

Boreal and alpine zones of the Central Scandes with an oceanic climate, form climatically and topographically optimal range for sloping fens (Sjörs 1946, Moen 1990, 1999, Joosten et al. 2017). Vegetation described by Sjörs (1946) (at $600 \mathrm{~m}$ a.s.1., Sweden) highlight the poorrich gradient that included close counterparts to lawn-fen communities of extremely poor to rich fens described by Havas (1961). Additionally, Sjörs (1946: 12) described small areas of sloping fens with flarks. Ptilidium ciliare was more frequent in Trichophorum lawn communities of the Central Scandes than in communities of $\mathrm{E}$ Finland, and oceanic Narthecium ossifragum as well as slightly oceanic Sphagnum pulchrum were dominants. Using TWINSPAN, Moen et al. (2011) classified the vegetation of sloping rich-fen lawns in an area in central Norway close to the one studied by Sjörs (1948). They identified two communities - both having southern Carex hostiana and Succisa pratensis and alpine Thalictrum alpinum — not occuring in eastern Finnish sloping fens (Havas 1961). One of those communities identified by TWINSPAN was in the oceanic area at the elevation of $380-490 \mathrm{~m}$ a.s.1. (precipitation $1583 \mathrm{~mm}$ ) and included oceanic Erica tetralix, and that at the less oceanic area at $700-800 \mathrm{~m}$ a.s.1. (precipitation $637 \mathrm{~mm}$ ) included the alpine species Kobresia simpliciuscula, Saxifraga aizoides, Pedicularis oederi, and Juncus triglumis that were not found by Havas (1961).
The subalpine northern Scandinavian sloping fens described by Persson (1962) from northern Sweden (350-650 m a.s.1.) lacked Molinia caerulea which is frequent in sloping fens in milder and more oceanic parts of Fennoscandia (Auer 1922, Sjörs 1946, Havas 1961, Laitinen et al. 2011, Moen et al. 2011). Persson (1962: fig. 19) arranged communities two-dimensionally, i.e. along the bog-poor-fen-rich-fen gradient and along the mire surface levels, and studied mire margin communities outside those gradients. He described an Trichophorum cespitosum-Calliergon sarmentosum-Drepanocladus badius association of intermediate fens, which Havas (1961) did not consider, but for which Ruuhijärvi (1960) and Laitinen et al. (2011) found resembling types with Molinia from sloping fens in the Finnish aapa mire area. Intermediate fens are characterized by certain mid- to northern boreal mosses, such as Loeskypnum badium, Sphagnum subfulvum and Warnstorfia sarmentosa (BraumooreWeissmoore; Ruuhijärvi 1960). Rydin et al. (1999) regarded intermediate fens as specifically boreal vegetation. Their assumed restricted distribution perhaps is partly due to unclear terminology or definitions, as noted by Hájek et al. (2006), who regarded 'intermediate fen' as a rarely recognized category. According to Havas (1961), however, intermediate fens (community 3 ) are a heterogeneous group with ecologically varying dominants, mostly with widely distributed $S$. warnstorfii (see Mikulášková et al. 2014, Laine et al. 2018).

\section{Comparable vegetation in central and southeastern Europe}

Sekulová et al. (2011) reported the Trichophoro cespitosi-Sphagnetum compacti association (Waren 1926) - analogous to community 1 of Havas (1961) - from the West Carpathians, in a subalpine-alpine belt in the nemoral zone in Slovakia and Poland (1500-2100 m a.s.l., precipitation $>1200 \mathrm{~mm}$, mean annual temperature is $\sim 0{ }^{\circ} \mathrm{C}$ ). We found this boreal community at the highest elevations (350-400 $\mathrm{m}$ a.s.1.) among the communities of sloping fens but it had no true alpine species. Similarly, among Bulgarian highmountain fen communities, Sphagnum compactum was most frequently present at the high- 
est elevations (2100-2500 m a.s.l.) (Hájková et al. 2006). The Carpathian Trichophoro cespitosi-Sphagnetum compacti association includes alpine species (Homogyne alpina, Campanula alpina and Soldanella carpatica), while the boreal Betula nana, Rubus chamaemorus, and Sphagnum lindbergii are lacking. Sekulová et al. (2011) classified the Carpathian community into Oxycocco-Sphagnetea class (mainly bogs).

The Molinia caerulea-Trichophorum cespitosum-Sphagnum compactum-S. papillosum community 2 of Havas (1961) had no analogous vegetation in the West Carpathians (Sekulová et al. 2011) or in the Bulgarian mountains (Hájková et al. 2006).

Peterka et al. (2014) reported a Sphagno warnstorfi-Tomentypnion alliance from the Bohemian-Moravian highlands in the Czech Republic at the elevation between $450-730 \mathrm{~m}$ a.s.l., in the nemoral zone in (annual precipitation 600-900 m, mean annual temperature 5.0$6.5^{\circ} \mathrm{C}$ ). This is a major phytosociological vegetation type restricted to protected areas and annually mown sites having numerous threatened or regionally rare species (Trichophorum alpinum, Carex dioica, C. chordorrhiza, C. limosa, e.g.). The community resembled community 6 (Carex magellanica-Filipendula ulmaria-Sphagnum warnstorfii community) of Havas (1961), corresponding to boreal mire site type Sphagnum warnstorfianum rich fens (Braunmoore; Ruuhijärvi 1960). This rich-fen habitat (rich Sphagnum fen, Hájek et al. 2006) hosted boreal brown mosses (Tomentypnum nitens, Paludella squarrosa), which are considered glacial relicts in central Europe (Rybníček 1966).

Conradi and Fiedmann (2013) reported a small-sedge rich fen Amblystegio stellate-Caricetum dioicae community (Osvald 1925) from the Northern Limestone Alps in the montane belt of the nemoral zone in Germany (elevation $1100 \mathrm{~m}$ a.s.l., annual prepicitation $1750 \mathrm{~mm}$, mean annual temperature $5{ }^{\circ} \mathrm{C}$ ). This community can be considered analogous to rich-fen sub-communities 4.1 and 4.2 of Havas (1961), which correspond to a generally recognized boreal (Finnish) mire site type Campylium stellatum rich fens (Braunmoore; Ruuhijärvi 1960). Trichophorum cespitosum was frequent and partly dominant in the montane community as in boreal communities of Havas (1961) (but see Dítě et al. 2007: 404). In our study area, small cover of Sphagnum subsecundum and $S$. warnstorfii was a common feature with that in corresponding boreal rich lawn fens. Conradi and Friedmann (2013) placed the Amblystegio stellate-Cari-cetum dioicae community of the Alps in a rich-fen alliance Caricion davallianae (Sheuchzerio palustris-Caricetea fuscae class). However, they paid attention also to the presence of Oxycocco-Sphagnetea species (Drosera rotundifolia, Vaccinium oxycoccos), which is a feature common to mid- to northern boreal rich fens (Ruuhijärvi 1960, Havas 1961, Heikkilä 1987, Moen 1990, Moen et al. 2011).

The Bulgarian high-mountain fen communities (Hájek et al. 2005, Hájková et al. 2006) in southeastearn Europe clearly deviate from those of the eastern Finnish sloping fens by having species typical for the Balkan region. However, the most common fen-community in the Vitosha Mountains (Cirsio heterotrichi-Caricetum nigrae) includes the group of 'Molinion species' (Molinia caerulea, Succisa pratensis, Sanquisorba officinalis, Potentilla erecta; Hájek et al. 2005) and Trichophorum cespitosum (belonging to Molinia species groups of Havas 1961). As Hájková et al. (2006) stated that Molinion species occur at temporarily wet sites, one may regard that species group as a southern ecological equivalent of the boreal Molinia group of Havas (1961), indicating unstable water regime. Thus, a peculiar vegetation-ecological feature characteristic of boreal oceanic sloping fens is present in a community of high-mountain alpine fens in southeastern Europe. On the other hand, the species representing the Molinion group of Hájek et al. (2005) are less frequent and much more dispersed across different communities within the sub-mountain mire associations of Bulgaria (Hájek et al. 2008). This fact further highlights certain ecological similarities among boreal sloping fens and montane-subalpinealpine fens of more southern vegetation zones.

\section{Conclusion}

We suggest that the approach of Sjörs (1948) with three mire gradients, and that of Hájek et 
al. (2006) with two main gradients based on $\mathrm{pH}$ and calcium (poor-rich gradient), and fertility are basically similar, with differences between them resulting from different study scales (size of surface-level patterns, sample-plot sizes and extent of the study area), study methods, research approaches and terminologies. To us, it seems that the poor-rich gradient, related to $\mathrm{pH}$ and base cations, is the general (common) primary gradient in fen vegetation across all regions. The other gradients are associated with wetness (mire surface level), amounts of nutrients (fertility, mire margin-expanse) (Jiménez-Alfaro et al. 2013), or geographic-macroclimatic variation evident in continental scale vegetation surveys (Peterka et al. 2017). The gradient from stable to unstable water regimes plays a role in exceptional peatforming conditions as in the boreal sloping fens (Auer 1922, Sjörs 1946, Havas 1961), in flat aapamire parts on water-permeable sand (Laitinen et al. 2005, 2008a, 2008b), and it shares some similarities with fen vegetation in subalpine-alpine belts of more southern vegetation zones.

The sloping fens in eastern Finland are diverse mires in the boreal zone, in a climate characterized by thermal continentality and hygric oceanity. They are structured along the poor-rich gradient and two vegetation-composition gradients. In general terms the vegetation gradients were complex and not directly comparable to those found elsewhere in Europe. Instead, we found some communities or vegetation types analogous across Europe, suggesting that European-wide classification schemes are feasible, while local variation deserves attention as well.

\section{Acknowledgements}

We thank professors Rauno Ruuhijärvi and Michal Hájek for advice, Mia Saarimaa for preparing the map and Tiina Kolari for comments. Tomáš Peterka was supported by the Czech Science Foundation (GX19-28491X), Teemu Tahvanainen by the Academy of Finland (project 311655, SHIFTMIRE), and Jarmo Laitinen by the Ministry of Environment, Finland (project LETTO-PUTTE).

\section{References}

Alalammi P. 1987: Climate. - In: Atlas of Finland: 131. National Board of Survey Geographical Society of Fin- land, Helsinki.

Alalammi P. 1990: Geology. — In: Atlas of Finland: 123126. National Board of Survey Geographical Society of Finland, Helsinki.

Auer V. 1922: Suotutkimuksia Kuusamon ja Kuolajärven vaara-alueilta [Moorforschungen in den Vaaragebieten von Kuusamo und Kuolajärvi] - Communicationes Instituto Quastetionum Forestalium Finlandiae 3(4): 1-71. [In Finnish with German summary].

Brandt A. 1948: Über die Entwicklung der Moore im Küstengebiet von Süd-Pohjanmaa am Bottnischen Meerbusen. - Annales Botanici Societatis Zoologicae Botanicae Fennicae Vanamo 23(4): 1-134.

Cajander A.K. 1913: Studien über die Moore Finnlands. Acta Forestalia Fennica 2(3): 1-208.

Conradi T. \& Friedmann A. 2013: Plant communities and environmental gradients in mires of the Ammergauer Alps (Bavaria, Germany). - Tuexenia 33: 133-163.

Cubizolle H. \& Thebaud J. 2014: A geographical model for the altitudinal zonation of mire types in the uplands of western Europe: the example of Les Monts du Forez in eastern France. - Mires and Peat 15, article 2, http://www.mires-and-peat.net/pages/volumes/map15/ map1502.php.

Dierssen K. 1982: Die wichtigsten Pflanzengesellschaften der Moore NE-Europas. — Conservatoire et Jardin botaniques, Genève.

Dítě D., Hájek M. \& Hájková P. 2007: Formal definitions of Slovakian mire plant associations and their application in regional research. - Biologia 62: 400-408.

Dítě D., Hájková P., Goia I. \& Hájek, M. 2015: Carex vaginata - new relict species in the Romanian flora. Contribuţii Botanice, Cluj-Napoca: Grădina Botanică “Alexandru Borza" 50: 7-13.

Douda J., Boublík K., Slezák M., Biurrun I., Nociar J., Havrdová A., Doudova J., Aćić S., Brisse H., Brunet J., Chytrý M., Claessens H., Csiky J., Didukh Y., Dimopoulos P., Dullinger S., FitzPatrick U., Guisan A., Horchler P.J., Hrivnák R., Jandt U., Kacki Z., Kevey B., Landucci F., Lecomte H., Lenoir J., Paal J., Paternoster D., Pauli H., Pielech R., Rodwell J.S., Roelandt B., Svenning J.-C., Šibík J., Šilc U., Škvorc Ž., Tsiripidis I., Tzonev R.T., Wohlgemuth T. \& Zimmermann N.E. 2015: Vegetation classification and biogeography of European floodplain forests and alder cars. - Applied Vegetation Science 19: 147-163.

Eurola S. 1962: Über die regionale Enteilung der südfinnischen Moore. - Annales Botanici Societatis Zoologicae Botanicae Fennicae Vanamo 33(2): 1-243.

Eurola S. \& Huttunen A. 2006: Mire plant species and their ecology in Finland. - The Finnish Environment 23: 127-144.

Eurola S. \& Kaakinen E. 1978: Suotyyppiopas. — WSOY, Porvoo.

Eurola S. \& Kaakinen E. 1982: The influence of an upland climate on the vegetation in the province of Kainuu, eastern Finland. - Aquilo, Ser. Botanica 18: 10-15.

Eurola S., Huttunen A., Huttunen M. \& Paasovaara P. 1982: Kaksi rinnesuota Riisitunturin kansallispuistossa [The nature of two sloping fens mires in the Riisitunturi 
National Park, northern Finland $\left.\left(66^{\circ} \mathrm{N} 15^{\prime} \mathrm{N}, 28^{\circ} 35^{\prime} \mathrm{E}\right)\right]$. - Suo 33: 75-79. [In Finnish with English summary].

Eurola S., Hicks S. \& Kaakinen E. 1984: Key to Finnish mire types. - In: Moore P.D. (ed.), European mires: 11-117. Academic Press, London.

Eurola S., Kaikkonen K., Leinonen S. \& Sepponen P. 1991: Forest vegetation of the province of Kainuu, eastern Finland (64' $\left.{ }^{\circ}, 2^{\prime} \mathrm{E}\right)$. - Aquilo, Ser. Botanica 30: 1-23.

Eurola S., Huttunen A. \& Kukko-oja K. 1995: Suokasvillisuusopas [Mire vegetation guide]. - Oulanka Reports 14: 1-85. [In Finnish with an English list of mire types].

Eurola S., Kaakinen E., Saari V., Huttunen A., Kukko-oja K. \& Salonen V. 2015: Sata suotyyppiä. Opas Suomen suokasvillisuuden tuntemiseen [Hundred mire site types]. - Thule Institut, Oulanka Research Station, University of Oulu. [In Finnish with an English list of mire site types].

Faith D.P., Minchin P.R. \& Belbin L. 1987: Compositional dissimilarity as a robust measure of ecological distance. - Vegetatio 69: 57-68.

Gräler B., Pebesma E. \& Heuvelink G. 2016: Spatio-temporal interpolation using gstat. - The $R$ Journal 8: 214-218. [Available at https://journal.r-project.org/ archive/2016/RJ-2016-014/RJ-2016-014.pdf].

Grünig A. 1994: Mire and man. Mire conservation in a densely populated country - the Swiss experience. Swiss Federal Institute for Forest, Snow and Landscape Research, Bimensdorf.

Gunnarsson U. \& Löfroth M. 2014: The Swedish wetland survey. - Naturvårdsverket, Report 6618: 1-37.

Hájek M., Hájková P., Apostolova I. 2008: New plant associations from Bulgarian mires. - Phytologia Balcanica 14: 377-399.

Hájek M., Horsák M., Hájkova P. \& Dítě D. 2006: Habitat diversity of central European fens in relation to environmental gradients and an effort to standardize fen terminology in ecological studies. - Perspectives in Plant Ecology, Evolution and Systematics 8: 97-114.

Hájek M., Tzonev R., Hájková P., Ganeva A. \& Apostolova I. 2005: Plant communities of the subalpine mires and springs in the Vitosha Mt. - Phytologia Balcanica 11: 193-205.

Hájková P. \& Hájek M 2003: Species richness and aboveground biomass of poor and calcareous spring fens in the flysch West Carpathians, and their relationships to water and soil chemistry. - Preslia 75: 271-278.

Hájková P., Hájek M. \& Apostilova A. 2006: Diversity of wetland vegetation in the Bulgarian high mountains, main gradients and context-depencence of the $\mathrm{pH}$ role. - Plant Ecology 184: 111-130.

Hájková P., Wolf P. \& Hájek M. 2004: Environmental factors and Carpathian spring fen vegetation: the importance of scale and temporal variation. - Annales Botanici Fennici 41: 249-262.

Hämet-Ahti L., Suominen J., Ulvinen T. \& Uotila P. (eds.) 1998: Retkeilykasvio, 4th ed. - Museum of Natural History, Botanical Museum, Helsinki.

Havas P. 1961: Vegetation und Ökologie der osfinnischen Hangmoore. - Annales Botanici Societatis Zoologicae Botanicae Fennicae Vanamo 31(2): 1-188.
Heikkilä H. 1987: The vegetation and ecology of mesotrophic and eutrophic fens in western Finland. Annales Botanici Fennici 24: 155-175.

Jiménez-Alfaro B., Hájek M., Ejrnaes R., Rodwell J., Pawlikkowski P., Weeda E.J., Laitinen J., Moen A., Bergamini A., Aunina L., Sekulová L., Tahvavainen T., Gillet F., Dítě D., Hájkova P., Corriol G., Kondelin H. \& Díaz T.E. 2013: Biogeographic patterns of base-rich fen vegetation across Europe. - Applied Vegetation Science 17: $367-380$.

Joosten H., Tanneberger F. \& Moen A. (eds.) 2017: Mires and peatlands of Europe. Status, distribution and conservation. - Schweizerbart Science Publishers, Stuttgart.

Kaakinen E., Kokko A., Aapala K., Autio O., Eurola S., Hotanen J-P., Kondelin H., Lindholm T., Nousiainen H., Rehell S., Ruuhijärvi R., Sallantaus T., Salminen P., Tahvanainen T., Tuominen S., Turunen J., Vasander H., Virtanen K. 2018: Suot [Mires]. — The Finnish Environment 5/2018, Part II: 325-474. [In Finnish with English summary].

Kruskal J.B. 1964. Multidimensional scaling by optimizing goodness-of-fit to a nonmetric hypothesis. - Psychometrika 29: 1-28.

Laine J., Flatberg K.I., Harju P., Timonen T., Minkkinen K., Laine A., Tuittila E.-S. \& Vasander H. 2018: Sphagnum mosses - the stars of European mires. - Sphagna, Helsinki.

Laitinen J. 2008: Vegetational and landscape level responses to water level fluctuations in Finnish, mid-boreal aapa mire - aro wetland environments. - Acta Universitatis Ouluensis A 513: 1-68.

Laitinen J., Rehell S. \& Huttunen A. 2005: Vegetationrelated hydrotopographic and hydrologic classification for aapa mires (Hirvisuo, Finland). — Annales Botanici Fennici 42: 107-121.

Laitinen J., Kukko-oja K. \& Huttunen A. 2008a: Stability of the water regime forms a vegetation gradient in minerotrophic mire expanse vegetation of a boreal aapa mire. - Annales Botanici Fennici 45: 342-359.

Laitinen J., Rehell S. \& Oksanen J. 2008b: Community and species responses to water level fluctuations with reference to soil layers in different habitats of mid-boreal mire complexes. - Plant Ecology 194: 17-36.

Laitinen J., Kondelin H. \& Heikkilä R. 2011: Intermediate fen patches on a sloping rock outcrop in Koitelainen, Finnish Lapland. - Mires and Peat 8, article 6, http:// mires-and-peat.net/pages/volumes/map08/map0806.php

Laitinen J., Oksanen J., Kaakinen E., Parviainen M., Küttim M. \& Ruuhijärvi R. 2017: Regional and vegetationecological patterns in northern boreal flark fens of Finnish Lapland: analysis form a classic material. - Annales Botanici Fennici 54: 179-195.

Laitinen J., Oksanen J., Hotanen J.-P., Kaakinen E., Saarimaa M. \& Ruuhijärvi R. 2019: Revised vegetation types in poor Picea abies mires (swamp forests) of Finland: ecological and geographical aspects. - Annales Botanici Fennici 56: 379-394.

Mikkonen M., Laine H.M., Mäkelä H., Gregow H., Tuomenvirta H., Lahtinen M. \& Laaksonen A. 2015: Trends in the average nemoral in Finland, 1847-2013. - Stochas- 
tic Environmental Risk and Research Assessment 29: $1521-1529$.

Mikulášková E., Hájek M., Veleba A., Johnson M.G., Hájek T \& Shaw J.A. 2014: Local adaptations in bryophytes revisited: the genetic structure of the calcium-tolerant peatmoss Sphagnum warnstorfii along geographic and pH gradients. - Ecology and Evolution 5: 229-242.

Minchin P.R. 1987: An evaluation of relative robustness of techniques for ecological ordinations. - Vegetatio 69: 89-107.

Moen A. 1990: The plant cover of the boreal uplands of central Norway. I. Vegetaton ecology of Sølendet nature reserve: haymaking fens and birch woodlands. - Gunneria 63: 1-451.

Moen A. 1999: National Atlas of Norway: Vegetation. Norwegian Mapping Authority, Hønefoss.

Moen A., Lyngstad A. \& Øien D.-I. 2011: Boreal rich fen vegetation formerly used for haymaking. - Nordic Journal of Botany 30: 226-240.

Mucina L., Bültmann H., Dierssen K., Theurillat J.-P., Raus T., Čarni A., Šumbernova K., Willner W., Dengler J., Gavilán, García R., Chytrý M., Hájek M., Di Pietro R., Iakushenko D., Pallas J., Daniëls F.J.A., Bergmeier E., Santos Guerra A., Ermakov N., Valachovič M., Schaminée J.H.J., Lysenko T., Didukh Y.A.P., Pignatti S., Rodwell J.S., Capelo J., Weber H.E., Solomeshch A., Dimopoulos P., Aguiar C., Hennekens S.M. \& Tichý L. 2016: Vegetation of Europe: hierarchical floristic classification system of vascular plant, bryophyte, lichen, and algal communities. - Applied Vegetation Science 19, Suppl 1: 3-264.

Økland R.H., Økland T. \& Rydgren K. 2001: A Scandinavian perspective on ecological gradients in north-west European mires: reply to Wheeler and Proctor. - Journal of Ecology 89: 481-486.

Osvald H. 1925: Zur Vegetation der ozeanischen Hochmoore in Norwegen. - Sveriges Växtsociologiska Sällskapets Handlingar 7: 1-106, Tafeln 1-16.

Paasovaara P. 1986: Riisitunturin alueen suotyypeistä. Oulun yliopiston Oulangan biologisen aseman monisteita 9: 51-85.

Pakarinen P. 1995: Classification of boreal mires in Finland and Scandinavia: A review. - Vegetatio 118: 29-38.

Pakarinen P. \& Ruuhijärvi R. 1978: Ordination of northern Finnish peatland vegetation with factor analysis and reciprocal averaging. - Annales Botanici Fennici 15: 147-157.

Pawlikowski P., Abramczyk K. \& Kozub Ł. 2013: Nitrogen: phosphorus ratio as the main ecological determinang of the differences in the species composition of brownmoss rich fens in north-eastern Poland. - Preslia 85: 349-367.

Persson Å. 1962: Mire and spring vegetation in an area north of lake Torneträsk, Torne Lappmark, Sweden. - Opera Botanica 6: 1-187.

Peterka T., Plesková Z., Jiroušek M. \& Hájek M. 2014: Testing floristic and environmental differentiation of rich fens on the Bohemian Massif. — Preslia 80: 337-366.

Peterka T., Hájek M., Jiroušek M., Jiménez-Alfaro B., Aunina L., Bergamini A., Dítě D., Felbaba-Klushyna L.,
Graf U., Hájková P., Hettenbergerová E., Ivchenko T.G., Jansen F., Koroleva N.E., Lapshina E.D., Lazarević P.M., Moen A., Napreenko M.G., Pawlikowski P., Plesková S., Sekulová L., Smagin V.A., Tahvanainen T., Thiele A., Bita-Nicolae C., Biurrun I., Brisse H., Ćušterevska R., De Bie E., Ewald J., FitzPatrick Ú., Front X., Jandt U., Kacki Z., Kuzemko A., Landucci F., Moeslund J.E., Pérez-Haase A., Rašomavičius V., Rodwell J.S., Schaminée J.H.J., Šilc U., Stančić Z. \& Chytrý M. 2017: Formalized classification of European fen vegetation at the alliance level. - Applied Vegetation Science 20: 124-142.

Rehell S., Laitinen J., Oksanen J. \& Siira O.-P. 2019: Mire margin to expanse gradient in part relates to nutrient gradient: evidence from successional mire basins, north Finland. - Mires and Peat 24, article 23, http://miresand-peat.net/pages/volumes/map24/map2423.php

Ruuhijärvi R. 1960: Über die Regionale Einteilung der Nordfinnischen Moore. - Annales Botanici Societatis Zoologicae Botanicae Fennicae Vanamo 3: 1-360.

Ruuhijärvi R. \& Lindholm T. 2006: Ecological gradients as the basis of Finnish mire site type system. - The Finnish Environment 23: 119-125.

Rybníček K. 1966: Glacial relics in the bryoflora of the highlands Českomoravská vrchovina (Bohemian-Moravian highlands), their habitat and cenotaxonomic value. Folia Geobotanica et Phytotaxonomica 1: 101-119.

Rydin H. 1985: Effect of water level on desiccation of Sphagnum in relation to surrounding Sphagna. _ Oikos 45: 374-379.

Rydin H., Sjörs H. \& Löfroth M. 1999: Mires. — Acta Phytogeographica Suecica 84: 91-112.

Sekulová L., Hájek M., Hájková P, Mikulášková E. \& Rozbrojová Z. 2011: Alpine wetlands in the West Carpathians: vegetation survey and vegetation-environment relationships. - Preslia 83: 1-24.

Simonen A. 1987: Pre-Quartenary rocks 1:1000 000. Atlas of Finland 123-126.

Singsaas S. 1989: Classification and ordination of the mire vegetation of Stormyra near Tynset, S Norway. Nordic Journal of Botany 9: 413-423.

Sjörs H. 1946: Myrvegetation i övre Långanområdet I Jämtland [The mire vegetation of upper Långan district in Jämtland, Sweden]. — Arkiv för Botanik 33: 1-96. [In Swedish with English summary].

Sjörs H. 1948: Myrvegetation i Bergslagen [Mire vegetation in Bergslagen, Sweden]. - Acta Phytogeographica Suecica 21: 1-290. [In Swedish with English summary].

Sjörs H. 1952: On the relation of vegetation and electrolytes in North Swedish mire waters. - Oikos 2: 241-258.

Sjörs H. \& Gunnarsson U. 2002: Calcium and $\mathrm{pH}$ in north and central Swedisn mire waters. - Journal of Ecology 90: 650-657.

Soó R. 1957: Pflanzengesellschaften aus Bulgarien. I. Annales Universitatis Scientiarum Budapestinensis de Rolando Eötvös Nominatae, Sect. Biol. 1: 231-239.

Söyrinki N., Salmela R. \& Suvanto J. 1977: Oulangan kansallispuiston metsä- ja suokasvillisuus. - Acta Forestalia Fennica 154: 1-150.

Steiner G.M. (ed.) 2005: Moore - von Siberien bis Feuer- 
land. - Oberösterreichisches Landesmuseum, Linz.

Stenroos S., Ahti T., Lohtander K. \& Myllys L. (eds.) 2011: Suomen jäkäläopas [Lichen flora of Finland]. - Kasvimuseo, Luonnontieteellinen keskusmuseo, Helsinki. [In Finnish with English summary].

Tahvanainen T. 2004: Water chemistry of mires in relation to the poor-rich vegetation gradient and contrasting geochemical zones of the north-eastern Fennoscandian Shield. — Folia Geobotanica 39: 353-369.

Tahvanainen T. \& Tuomaala T. 2003: The reliability of mire water $\mathrm{pH}$ measurements - a standard method. - Wetlands 23: 701-708.

Tolonen K. 1967: Über die Entwicklung der Moore im finnischen Nordkarelien. - Annales Botanici Fennici 4: 219-416.

Tuomikoski R. 1942: Untersuchungen über die Vegetation der Bruchmoore in Ostfinnland. I. Zur Methodik der pflanzensoziologischen Systematik. - Annales Botanici Societatis Zoologicae Botanicae Fennicae Vanamo 17:
$1-203$.

Tuomikoski R. 1955: Ruohoisuus ja luhtaisuus. - Suo 6: $1-18$.

Tyler C. 1984: Calcareous fens in south Sweden. Previous use, effects of management and recommendations. Biological Conservation 31: 69-89.

Ulvinen T., Syrjänen K. \& Anttila S. (eds.) 2002: Suomen sammalet - levinneisyys, ekologia, uhanalaisuus. Suomen Ympäristö 560: 1-354.

Vanderpuye A.S., Elvebakk A. \& Nilsen L. 2002: Plant communities along environmental gradients of high-arctic mires in Sassendalen, Svalbard. - Journal of Vegetation Science 13: 875-884.

Warén H. 1926: Untersuchungen über sphagnumreiche Pflanzengesellschaften der Moore Finnlands. - Acta Societatis pro Fauna et Flora Fennica 55: 1-113.

Zoltai S.C. \& Vitt D.H. 1995: Canadian wetlands: environmental gradients and classification. - Vegetatio 118: 131-137.

Appendix 1. Description of the study area.

\begin{tabular}{|c|c|c|c|c|}
\hline Topographic regions & Peripheral (P) & Northern uplands (NU) & Central hill range (CHR) & Southern hill range (SHR) \\
\hline Location & $\begin{array}{l}\text { E Kainuu, NE part of } \\
\text { North Karelia, E part of } \\
\text { Northern Ostrobothnia }\end{array}$ & Koillismaa & W Kainuu & $\begin{array}{l}\text { NW to middle part of North } \\
\text { Karelia }\end{array}$ \\
\hline Hilltop elevation (m a.s.I.) & $<300$ & $400-500$ & $300-380$ & Mainly 200-300 \\
\hline Vegetation on hilltops & $\begin{array}{l}\text { Pinus sylvestris and } \\
\text { Picea abies forests }\end{array}$ & $\begin{array}{l}\text { Picea abies forests, } \\
\text { exceptionally } \\
\text { treeless Calluna } \\
\text { heath resembling fjelds }\end{array}$ & $\begin{array}{l}\text { Picea abies forests, } \\
\text { site types common } \\
\text { at > } 300 \text { m a.s.l. }\end{array}$ & $\begin{array}{l}\text { Picea abies and } \\
\text { Pinus sylvestris forests }\end{array}$ \\
\hline Prevailing elevations (m a.s.I.) & $120-220$ & $\sim 250$ & $150-250$ & $120-200$ \\
\hline Sloping fens & Rare & Frequent & Relatively frequent & Rare \\
\hline Bedrock area & $\begin{array}{l}\text { Mainly siliceous } \\
\text { (granitic veins in } \\
\text { basement gneiss) }\end{array}$ & $\begin{array}{l}\text { Mainly siliceous } \\
\text { (granitic veins in } \\
\text { basement gneiss), } \\
\text { partly calcareous }\end{array}$ & Partly calcareous & $\begin{array}{l}\text { Siliceous (granitic veins } \\
\text { in basement gneiss), } \\
\text { partly calcareous }\end{array}$ \\
\hline Forest zone* & Mid-boreal forest & Northern boreal forest & Mid-boreal forest & $\begin{array}{l}\text { Southern margin of } \\
\text { mid-boreal forest }\end{array}$ \\
\hline Mire zone & Southern aapa mire & $\begin{array}{l}\text { Mainly main aapa } \\
\text { mire, partly } \\
\text { southern aapa mire }\end{array}$ & Southern aapa mire & $\begin{array}{l}\text { Southern aapa mire, } \\
\text { partly eccentric bog }\end{array}$ \\
\hline $\begin{array}{l}\text { Mowing and grazing in sloping } \\
\text { fens before the1950s }\end{array}$ & Rare & Rare & Common & Common \\
\hline Vulnerability of sloping fens & Vulnerable & Not threatened & Vulnerable & Largely threatened \\
\hline
\end{tabular}

* sensu Kalela (1961) 
Appendix 2. Indicator species groups. The groups are based mainly on the species groups in Havas (1961). Some species of contact habitats of boreal mires, occurring in the material, were added to show the continuum from mires into habitats other than mires.

L-Unstable = lawn species tolerant to unstable water regime (Molinia group)
Molinia caerulea
Selaginella selaginoides
Sphagnum tenellum
Trichophorum alpinum
Sphagnum compactum
Trichophorum cespitosum
S. papillosum
Ptilidium ciliare
Tofieldia pusilla
S. subfulvum
L-Stable = lawn species of extremely poor fens with stabile water regime (Eriophorum vaginatum group)
Andromeda polifolia Eriophorum vaginatum
Vaccinium oxycoccos
Drosera rotundifolia
Sphagnum magellanicum
S. angustifolium
Carex pauciflora

Campylium stellatum (also L-Rich)

L-Rich = rich-fen indicators of lawn fens (Campylium stellatum group)
Carex flava
C. panicea
Eriophorum latifolium

Campylium stellatum (also L-Unstable)

Scorpidium revolvens

Catoscopium nigritum

Cinclidium stygium

Flark = flark species (Menyanthes group)
Carex chordorrhiza
C. limosa
Drosera longifolia
C. rostrata
Menyanthes trifoliata
Rhynchospora alba

Hum-Pinus = hummock-level species of Pinus sylvestris mires (Empetrum group)
Pinus sylvestris

Calluna vulgaris

Chamaedaphne calyculata

\section{Empetrum nigrum s. lato}

Vaccinium microcarpum
Pseudocalliergon trifarium

Leiocolea rutheana (L. schulzii)

Aneura pinquis (Riccardia pinquis)

Utricularia minor

Sphagnum subsecundum

Scorpidium scorpioides

Hum-Picea $=$ hummock-level species of poor Picea abies mires (Carex globularis group)
Picea abies
Carex globularis
Equisetum sylvaticum
Vaccinium myrtillus

Sphagnum fuscum

Cladonia rangiferina

C. arbuscula (C. sylvatica)

Polytrichum commune

Herb-Picea $=$ species of herb-rich forests/Picea abies mires (Filipendula group) Filipendula ulmaria Convallaria majalis Geranium sylvaticum Paris quadrifolia Angelica sylvestris Rubus saxatilis

Spring = spring fen species (Paludella group) Paludella squarrosa Philonotis fontana Warnstorfia sarmentosa P. calcarea

Rhizomnium pseudopunctatum P. sp. Plagiomnium elatum

Carex vaginata

Meadow $=$ meadow species (Festuca group)

$\begin{array}{ll}\text { Agrostis canina } & \text { Carex nigra } \\ \text { A. capillaris } & \text { C. pallescens } \\ \text { Anthoxanthum odoratum } & \text { Achillea millefolium } \\ \text { Festuca ovina } & \text { Cirsium palustre } \\ \text { F. rubra } & \text { Galium palustre } \\ \text { Hierochloe hirta ssp. arctica } & \text { Prunella vulgaris } \\ \text { Nardus stricta } & \text { Ranunculus acris } \\ & \text { Rhinanthus minor }\end{array}$

Bryum pseudotriquetrum

Meesia uliginosa

Carex capillaris

Leucanthemum vulgare

Trifolium pratense

T. repens

Cerastium fontanum ssp. vulgare

Climacium dendroides

Fissidens adianthoides

Calliergonella lindbergii 
Appendix 3. Havas (1961) stand groups (Siedlungsgruppe), based on floristic similarities and differences, with sub-communities.

\section{Lawn groups}

1 Trichophorum cespitosum-Sphagnum compactum-Ptilidium ciliare stand group

2 Molinia caerulea-Trichophorum cespitosum-Sphagnum compactum-S. papillosum stand group

3 Molinia caerulea-Trichophorum cespitosum-Sphagnum warnstorfii stand group

4.1 Carex flava-Trichophorum cespitosum-Campylium stellatum stand group, Loeskypnum badium sub-community

4.2 Care flava-Trichophorum cespitosum-Campylium stellatum stand group, Pseudocalliergon trifarium sub-community

5.1 Carex flava-Filipendula ulmaria-Campylium stellatum stand group, Carex nigra sub-community.

5.2 Carex flava-Filipendula ulmaria-Campylium stellatum stand group, Saussurea alpina sub-community

6 Carex magellanica-Filipendula ulmaria-Sphagnum warnstorfii stand group

7 Betula nana-Eriophorum vaginatum-Sphagnum angustifolium stand group

8 Eriophorum vaginatum-Sphagnum lindbergii-S. russowii stand group

Hummock-level groups

9 Carex globularis-Sphagnum fuscum-S. russowii stand group

10 Vaccinium uliginosum-Sphagnum fuscum-S. angustifolium stand group

11 Calluna vulgaris-Molinia caerulea-Sphagnum fuscum stand group

Flark vegetation

12 Flark (rimpi) vegetation 